\title{
Communities of the association Melilotetum albo-officinalis Sissingh 1950 in the European part of Russia and Belarus
}

\author{
Ludmila Arepieva ${ }^{1}$, Elena Kulikova ${ }^{2}$, Larisa Abramova ${ }^{3}$, Yaroslav Golovanov ${ }^{3}$, Alexey \\ Bulokhov4, Andrey Kharin ${ }^{4}$ \\ ${ }^{1}$ Kursk State University, Kursk Oblast, Kursk, 33, Radishcheva St., 305000, Russian Federation; \\ ludmilla-m@mail.ru \\ 2 V.F. Kuprevich Institute of Experimental Botany of the National Academy of Sciences of Belarus, \\ Minsk Oblast, Minsk, 27, Akademicheskaya St., 220072, Belarus; kulikova22@mail.ru \\ ${ }^{3}$ South-Ural Botanical Garden-Institute, Ufa Federal Scientific Center, Russian Academy of Sciences, \\ Republic of Bashkortostan, Ufa, 195/3, Mendeleeva St., 450080, Russian Federation; \\ abramova.Im@mail.ru; jaro1986@mail.ru \\ ${ }^{4}$ Academician I.G. Petrovskii Bryansk State University, Bryansk Oblast, Bryansk, 14, Bezhitskaya St., \\ 241036, Russian Federation; kafbot2002@mail.ru, avbr1970@yandex.ru
}

Arepieva L., Kulikova E., Abramova L., Golovanov Y., Bulokhov A. \& Kharin A. (2020): Communities of the association Melilotetum albo-officinalis Sissingh 1950 in the European part of Russia and Belarus. - Thaiszia - J. Bot. 30 (2): 161-186.

Abstract: The purpose of the study is to revise relevés of synanthropic communities dominated by Melilotus albus and $M$. officinalis from forest, forest-steppe and steppe zones of the European part of Russia and Belarus and to reveal the variation in their floristic composition in this territory. In the present paper, 66 relevés from 2004 to 2016 are analyzed. As a result of the study, the association Melilotetum albo-officinalis was identified. It includes three subassociations that reflect different ecological conditions and some geographical distribution features of communities. Subass. typicum includes the most typical communities. It has two variants. Communities of var. typica often contain few species due to the strong dominance of Melilotus albus and M. officinalis. Var. Ambrosia artemisiifolia includes early successional phytocoenoses affected by regular disturbances. The mesophytic communities which are rich in mesophilous meadow and ruderal species are assigned to the subass. tussilaginetosum farfarae. They tend to spread in the northwestern part of the study area located in the forest zone. Subass. carduetosum acanthoidis includes xeromesophytic communities. Its coenoflora contains highly constant species of the order Onopordetalia acanthi and a high proportion of subcontinental and continental species. They are widespread in the eastern part of the study area, in steppe and forest-steppe zones. Environmental differences 
between habitats of the described communities are shown using targeted ecological indicator values. The highest variability between syntaxa was identified in the levels of moisture in soils and substrates, temperature, continentality and hemeroby.

Keywords: syntaxonomy, ass. Melilotetum albo-officinalis, subassociations, variants, ecological differentiation, geographical distribution of plant communities.

\section{Introduction}

Identification of geographical patterns of plant communities' distribution is an important task of modern geobotany. A special topic in this field of science is the study of changes in the species composition of synanthropic plant communities along a geographical gradient. As a result of human impact in different natural zones, vegetation with a similar syntaxonomic structure is formed on anthropogenic habitats, and therefore many associations of synanthropic vegetation have a wide distribution area. However, under the influence of natural factors throughout the area, there is a change in their floristic composition in both latitudinal and longitudinal directions.

A great contribution to the study of changes in the species composition of synanthropic communities along a geographical gradient was made by D. Brandes and L. Mucina. They described the distribution patterns in Europe of many associations: Berteroetum incanae Sissingh et Tideman ex Sissingh 1950 (Mucina \& Brandes 1985), Malvetum neglectae Felf. 1942 (Brandes 1981), Sambucetum ebuli Felföldy 1942 (Brandes 1982), Torilidetum japonicae Lohmeyer ex Görs et Müller 1969 (Mucina 1991), associations with Onopordum acanthium (Mucina 1989) and others. To analyze and identify patterns, the authors used a large number of relevés recorded mainly in Western and Central Europe, as well as in some regions of Eastern Europe. From the more continental regions, less relevés was presented due to the insufficient geobotanical exploration of these regions. Therefore, for the territory of European Russia and the near abroad, there is little information on the geographical differentiation of synanthropic communities (Ishbirdin et al. 1988; Solomakha et al. 1992).

In recent decades, synanthropic vegetation has been actively studied in the European part of Russia and neighboring countries. Publications show a fairly high diversity of synanthropic communities, however, this type of vegetation is still not fully understood. For the most complete identification of the ecological and geographical features of synanthropic vegetation in this territory, it is necessary to revise and summarize the accumulated syntaxonomic information, which requires coordination of research in different regions (Abramova \& Golovanov 2016).

In this study, a team of authors from different parts of the European part of Russia and Belarus analyses the accumulated syntaxonomic information on communities, widespread in anthropogenic habitats and dominated by Melilotus albus and $M$. 
officinalis. In the study area, these phytocoenoses were identified as the Melilotetum albo-officinalis Sissingh 1950 or as basal communities of the appropriate alliance. Many authors believe that these communities belong to the same association (Jarolímek et al. 1997; Schubert 2001; Borhidi 2003; Chytrý 2009). The purpose of the study is to compile a set of relevés of synanthropic communities with Melilotus albus and $M$. officinalis from forest, forest-steppe and steppe zones of the European part of Russia and Belarus and to assess the variation in their floristic composition in this territory.

\section{Material and Methods}

In the present study, 66 relevés are analyzed. They were recorded by the authors of this article from 2004 to 2016 in the European part of Russia (the city of Kursk and few district centers of the Kursk region, the city of Bryansk in Bryansk region, the towns of Sterlitamak and Salavat in the Republic of Bashkortostan) and in the Republic of Belarus (the city of Minsk) (Fig. 1). Some information about natural conditions in the study area is given in Tab. 1.

The size of the plot relevés varied from 4 to $64 \mathrm{~m}^{2}$. Plant cover was assessed in percentages (\%), converting to values on the Braun-Blanquet combined scale: $r-$ the species is extremely rare; + - the species is rare; 1 - plant cover up to $5 \% ; 2$ cover from $6 \%$ to $25 \%$; 3 - cover from $26 \%$ to $50 \%$; 4 - cover from $51 \%$ to $75 \%$; 5 - cover more than $75 \%$ (Braun-Blanquet 1964). The tree species in the tables are represented by seedlings or juvenile stage.

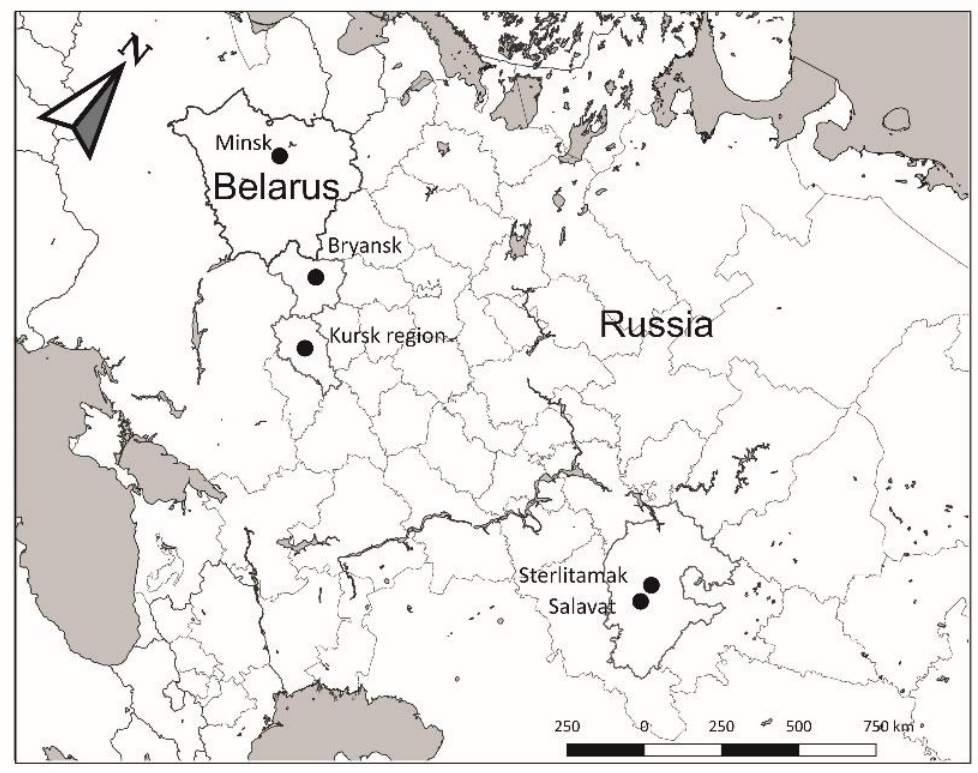

Fig. 1 The scheme of study area and localities of relevés. 
Tab. 1 (Bio)geographic and climatic characteristics of the studied areas.

\begin{tabular}{lccccc}
\hline \multicolumn{1}{c}{ Indicator } & Minsk & Bryansk & Kursk region & Sterlitamak & Salavat \\
\hline Coordinates & $\begin{array}{c}53^{\circ} 54^{\prime} 07^{\prime \prime} \mathrm{N}, \\
27^{\circ} 33^{\prime} 31^{\prime \prime} \mathrm{E}\end{array}$ & $\begin{array}{c}53^{\circ} 15^{\prime} 40^{\prime \prime} \mathrm{N}, \\
34^{\circ} 22^{\prime} 30^{\prime \prime} \mathrm{E}\end{array}$ & $\begin{array}{c}51^{\circ} 31^{\prime} 11^{\prime \prime}-52^{\circ} 20^{\prime} 21^{\prime \prime} \mathrm{N}, \\
35^{\circ} 21^{\prime} 06^{\prime \prime}-38^{\circ} 01^{\prime} 46^{\prime \prime} \mathrm{E}\end{array}$ & $\begin{array}{c}53^{\circ} 38^{\prime} 00^{\prime \prime} \mathrm{N}, \\
55^{\circ} 57^{\prime} 00^{\prime \prime} \mathrm{E}\end{array}$ & $\begin{array}{c}53^{\circ} 22^{\prime} 00^{\prime \prime} \mathrm{N}, \\
55^{\circ} 56^{\prime} 00^{\prime \prime} \mathrm{E}\end{array}$ \\
\hline $\begin{array}{l}\text { Average } \\
\text { annual } \\
\text { temperature }\end{array}$ & $+6.7^{\circ} \mathrm{C}$ & $+6.2^{\circ} \mathrm{C}$ & $+5.9-7.1^{\circ} \mathrm{C}$ & $+3.2^{\circ} \mathrm{C}$ & $+3.6^{\circ} \mathrm{C}$ \\
\hline $\begin{array}{l}\text { Average } \\
\text { annual } \\
\text { rainfall }\end{array}$ & $700 \mathrm{~mm}$ & $683 \mathrm{~mm}$ & $475-640 \mathrm{~mm}$ & $498.9 \mathrm{~mm}$ & $576 \mathrm{~mm}$ \\
$\begin{array}{l}\text { Zonal soil } \\
\text { types }\end{array}$ & sod-podzolic & $\begin{array}{c}\text { podzolic, sod- } \\
\text { podzolic, gray } \\
\text { forest soil }\end{array}$ & $\begin{array}{c}\text { chernozem, dark gray } \\
\text { forest soil }\end{array}$ & chernozem & chernozem \\
\hline $\begin{array}{l}\text { Zonal } \\
\text { vegetation } \\
\text { types }\end{array}$ & $\begin{array}{c}\text { conifer- } \\
\text { broadleaf } \\
\text { forests }\end{array}$ & $\begin{array}{c}\text { conifer- } \\
\text { broadleaf and } \\
\text { broadleaf } \\
\text { forests }\end{array}$ & $\begin{array}{c}\text { broad-leaved forests } \\
\text { and meadow steppes }\end{array}$ & $\begin{array}{c}\text { steppes and } \\
\text { forest- } \\
\text { steppes }\end{array}$ & steppes \\
\hline
\end{tabular}

Relevés were processed according to the Braun-Blanquet approach (BraunBlanquet 1964; Westhoff \& van der Maarel 1973) with the use of software packages TURBOVEG (Hennekens 1995), JUICE (Tichý 2002), IBIS (Zverev 2007). We used the program CANOCO 4.5 (Ter Braak \& Šmilauer 2002) for DCA- ordination.

Diagnostic species of subassociations and variants were identified based on the algorithms described in the Vegetation of the Czech Republic book series (e.g. Chytrý 2009) using the software package JUICE (Tichý 2002). To identify diagnostic species, the phi fidelity index was used (Chytrý et al. 2002). Fidelity was calculated using presence-absence data with standardization of all groups of relevés to equal size. Using Fischer's exact test, non-significant species $(p<0.001)$ were assigned zero fidelity. In this work, the diagnostic species were not subdivided into diagnostic and highly diagnostic species. A species was denoted as diagnostic, if the phi coefficient's value was above 0.5 .

Identification of diagnostic species of higher syntaxa was carried out using the available phytosociological literature (e.g. Jarolímek et al. 1997; Dengler \& Wollert 2004; Chytrý 2007, 2009; Solomakha 2008; Mirkin \& Naumova 2012; Mucina et al. 2016). Ecological conditions of communities' habitat, such as soil moisture, reaction, richness in mineral nitrogen, light, temperature and continentality were assessed using average Ellenberg ecological indicator values (Ellenberg et al. 1992). Hemeroby was assessed using average values of N. G. Ilminskikh (1993) ecological 9-point scale in the software package IBIS (Zverev 2007). These indicator values for each syntaxon are reported in box-and-whiskers plots (Fig 2). Significant differences between pairs of syntaxons for each environmental factor were determined by the Mann-Whitney $U$-test in the PAST package (Hammer et al. 2001). Syntaxon names follow the International Code of Phytosociological Nomenclature (Weber et al. 2000). Species names follow The Plant List (http://www.theplantlist.org). Species names of the genus Oenothera L. follow Rostanski et al. (2004). 

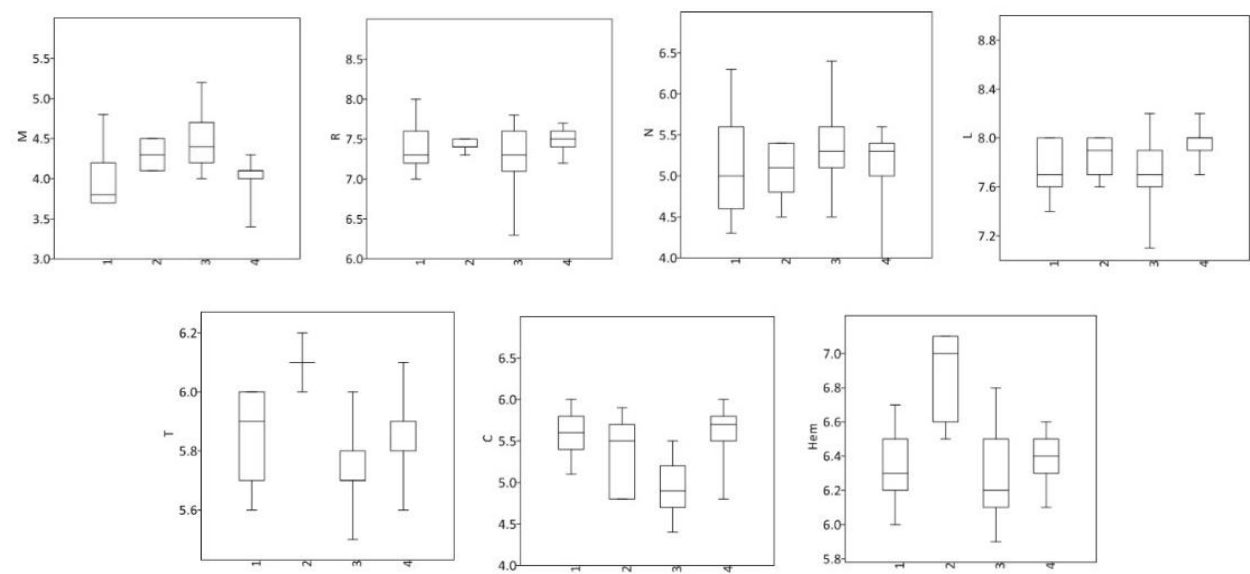

Fig. 2 Value ranges of ecological factors for syntaxa. Rectangles - interquartile range (25-75\% of observed values); horizontal lines inside rectangles - the median values; vertical lines outside rectangles - minimal and maximal values. $M$ - soil moisture, $\mathrm{R}$ - soil reaction, $\mathrm{N}$ - soil richness in mineral nitrogen, $\mathrm{L}$ - light, $\mathrm{T}$ temperature, $\mathrm{C}$ - continentality, Hem - hemeroby. 1-4 - syntaxa: 1 - subass. typicum var. typica, 2 - subass. typicum var. Ambrosia artemisiifolia, 3 - subass. tussilaginetosum farfarae, 4 - subass. carduetosum acanthoidis.

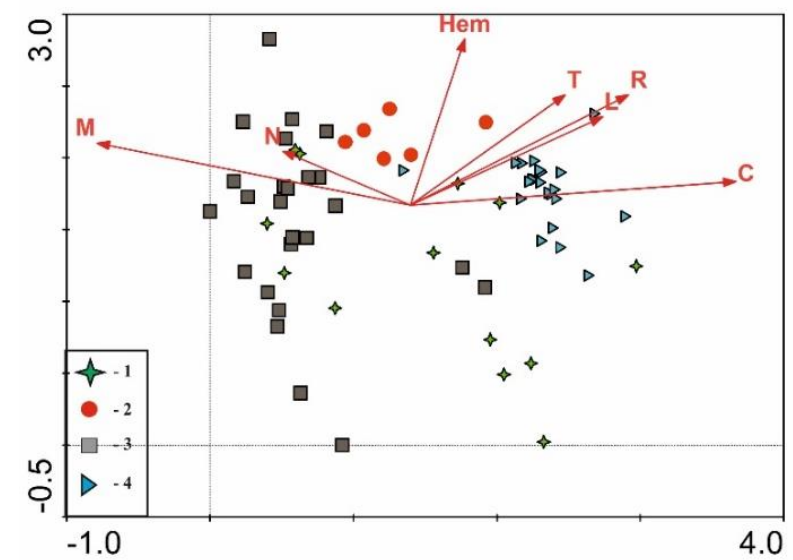

Fig. 3 DCA ordination of relevés by ecological factors. 1-4 - syntaxa. Numbers of syntaxa and symbols of ecological factors: see note to Fig. 2.

\section{Results}

As a result of the analysis of relevés, the association Melilotetum albo-officinalis Sissingh 1950 was identified. It comprises 3 subassociations and 2 variants. The classification scheme and characteristics of syntaxa are given below. 
Class Artemisietea vulgaris Lohmeyer et al. ex von Rochow 1951

Order Onopordetalia acanthii Br.-BI. et Tx. ex Klika et Hadač 1944

Alliance Dauco-Melilotion Görs ex Rostański et Gutte 1971

Ass. Melilotetum albo-officinalis Sissingh 1950

Subass. typicum Passarge 1977

Var. typica

Var. Ambrosia artemisiifolia

Subass. Melilotetum albo-officinalis tussilaginetosum farfarae Jarolímek et al. 1997

Subass. Melilotetum albo-officinalis carduetosum acanthoidis subass. nov. hoc loco

Ass. Melilotetum albo-officinalis Sissingh 1950 (Tab. 2)

Synonyms: Echio-Melilotetum Tüxen 1947 (§ 3f), Echio-Verbascetum Sissingh 1950 (§ 25), Artemisio-Melilotetum albi Hadač 1978

Melilotus albus and $M$. officinalis are used as diagnostic species of the association Melilotetum albo-officinalis. This combination can be corrected in future work when relevés of other associations of the alliance Dauco-Melilotion Görs ex Rostański et Gutte 1971 in the study area will be processed.

The name-giving species of the association, Melilotus albus and M. officinalis, determine the physiognomy of communities. They dominate in communities together or separately. The total plant cover varies from 30 to $100 \%$. Communities have two layers. The upper layer $(70-100 \mathrm{~cm})$ is composed of diagnostic species, Artemisia absinthium, A. vulgaris, Cichorium intybus, Cirsium arvense, Elytrigia repens, Pastinaca sativa, Tanacetum vulgare. The lower layer $(10-40 \mathrm{~cm})$ is formed by Achillea millefolium, Medicago lupulina, Poa angustifolia, P. compressa, $P$. pratensis, Plantago major, Taraxacum officinale. The number of species per relevé is 6-39. In total, there were 193 species recorded in the coenoflora of the association.

Species of orders Onopordetalia acanthii (Artemisia absinthium, Cichorium intybus, Pastinaca sativa), Agropyretalia intermedio-repentis T. Müller et Görs 1969 (Elytrigia repens, Convolvulus arvensis), classes Artemisietea vulgaris (Artemisia vulgaris, Cirsium arvense) and Molinio-Arrhenatheretea (Achillea millefolium, Taraxacum officinale, Trifolium pratense) are represented in the association with high constancy.

Phytocoenoses are formed in well lit (7.1-8.2 Ellenberg ecological indicator value) and moderately warm (5.5-6.2) habitats on dry and moderately moist (3.4-5.2), slightly acidic, neutral and slightly alkaline (6.3-8.0) soils and substrates with various granulometric composition, slightly to moderately rich in mineral nitrogen (4.0-6.4). They occur on construction sites, wastelands, railway embankments, near housing, along roads and banks of reservoirs. 
Tab. 2 Shortened synoptic table of the association Melilotetum albo-officinalis in the study area with percentage frequencies and phi fidelity indices (in the superscript). Only species with at least $20 \%$ constancy in any syntaxon are shown. For full species composition, see Tab. 3, 4 .

\begin{tabular}{|c|c|c|c|c|}
\hline \multirow[b]{2}{*}{ Subassociations and variants } & \multicolumn{2}{|c|}{ subass. typicum } & \multirow{2}{*}{$\begin{array}{c}\text { subass. } \\
\text { tussilaginetosum } \\
\text { farfarae }\end{array}$} & \multirow{2}{*}{$\begin{array}{c}\text { subass. } \\
\text { carduetosum } \\
\text { acanthoidis }\end{array}$} \\
\hline & var. typica & $\begin{array}{c}\text { var. Ambrosia } \\
\text { artemisiifolia }\end{array}$ & & \\
\hline Number of relevés & 13 & 6 & 25 & 22 \\
\hline Number in table & 1 & 2 & 3 & 4 \\
\hline \multicolumn{5}{|c|}{ D. s. of the ass. Melilotetum albo-officinalis, subass. typicum and var. typica } \\
\hline Melilotus officinalis & 62 & $100^{37.6}$ & 24 & $95^{31.8}$ \\
\hline Melilotus albus & 38 & $83^{24.7}$ & $88^{30.2}$ & 41 \\
\hline \multicolumn{5}{|c|}{ D. s. of the var. Ambrosia artemisiifolia } \\
\hline Ambrosia artemisiifolia & . & $100^{97.4}$ & 4 & . \\
\hline Xanthium albinum & . & $100^{94.3}$ & . & 9 \\
\hline Lotus corniculatus & 8 & $100^{80.6}$ & 28 & . \\
\hline Oenothera rubricaulis & 8 & $83^{80.8}$ & 4 & . \\
\hline Lactuca serriola & . & $83^{69.8}$ & 4 & 27 \\
\hline Acer negundo & 8 & $67^{62.9}$ & 8 & 5 \\
\hline Setaria viridis & . & $50^{61.2}$ & . & 5 \\
\hline Centaurea pseudomaculosa & . & $50^{57.8}$ & 4 & 5 \\
\hline Eragrostis minor & . & $33^{52.2}$ & . & . \\
\hline \multicolumn{5}{|c|}{ D. s. of the subass. tussilaginetosum farfarae } \\
\hline Dactylis glomerata & 15 & . & $88^{79.4}$ & 5 \\
\hline Festuca pratensis & 8 & . & $52^{60.1}$ & . \\
\hline Daucus carota & 15 & . & $52^{51.1}$ & 5 \\
\hline Phleum pratense & . & . & $44^{56.3}$ & 5 \\
\hline Agrostis gigantea & . & . & $40^{53.0}$ & 5 \\
\hline Tussilago farfara & . & . & $28^{51.1}$ & . \\
\hline \multicolumn{5}{|c|}{ D. s. of the subass. carduetosum acanthoidis } \\
\hline Carduus acanthoides & . & 17 & 8 & 9179.0 \\
\hline Arctium tomentosum & 15 & . & 20 & $73^{59.4}$ \\
\hline Linaria vulgaris & 8 & $33^{3.6}$ & 8 & $73^{53.1}$ \\
\hline Pastinaca sativa & 15 & . & $44^{12}$ & $77^{52.5}$ \\
\hline \multicolumn{5}{|c|}{ D.s. of the all. Dauco-Melilotion and ord. Onopordetalia acanthii } \\
\hline Artemisia absinthium & $69^{2.1}$ & 67 & 48 & $86^{23.2}$ \\
\hline Cichorium intybus & 38 & 677.2 & 60 & $77^{19.7}$ \\
\hline Tanacetum vulgare & $31^{6.1}$ & $33^{9.4}$ & $36^{12.9}$ & 5 \\
\hline Echium vulgare & 15 & 6729.2 & 12 & $73^{36.3}$ \\
\hline Berteroa incana & $38^{10.6}$ & 17 & 24 & $41^{13.7}$ \\
\hline Euphorbia virgata & 23 & . & 24 & $64^{46.4}$ \\
\hline Picris hieracioides & . & 3324.8 & 8 & $27^{15.5}$ \\
\hline Potentilla argentea & $15^{9.1}$ & . & 4 & $23^{22.9}$ \\
\hline Cynoglossum officinale & . & . & . & $23^{42.5}$ \\
\hline \multicolumn{5}{|c|}{ D.s. of the ord. Agropyretalia intermedio-repentis } \\
\hline Elytrigia repens & 69 & $100^{35.8}$ & 56 & 64 \\
\hline Convolvulus arvensis & 54 & $100^{40.3}$ & 24 & $91^{29.2}$ \\
\hline Poa compressa & 31 & $83^{48.6}$ & $44^{2.6}$ & 9 \\
\hline Poa angustifolia & 15 & 17 & 8 & $50^{38}$ \\
\hline Calamagrostis epigeios & $38^{5.1}$ & $67^{39.4}$ & 32 & . \\
\hline
\end{tabular}


Tab. 2 - cont.

\begin{tabular}{|c|c|c|c|c|}
\hline Number in tabl. & 1 & 2 & 3 & 4 \\
\hline Bromopsis inermis & 8 & . & 8 & $36^{40.1}$ \\
\hline \multicolumn{5}{|c|}{ D.s. of the cl. Artemisietea vulgaris } \\
\hline Artemisia vulgaris & 54 & 67 & 64 & $86^{23}$ \\
\hline Cirsium arvense & 31 & 17 & 40 & $73^{38.5}$ \\
\hline Erigeron annuus & $54^{39.2}$ & . & $40^{20.6}$ & 5 \\
\hline \multicolumn{5}{|l|}{ D.s. of the cl. Sisymbrietea } \\
\hline Erigeron canadensis & 15 & $50^{39.5}$ & 8 & 14 \\
\hline Chenopodium album & 8 & $50^{46}$ & 4 & 14 \\
\hline Sisymbrium loeselii & 15 & $33^{10.3}$ & 8 & $45^{26.4}$ \\
\hline Tripleurospermum inodorum & 15 & . & 24 & 5946.2 \\
\hline Lactuca tatarica & 8 & $33^{33.1}$ & . & 14 \\
\hline Senecio vulgaris & $23^{33}$ & . & $8^{0.5}$ & . \\
\hline Sonchus arvensis & . & . & . & $27^{46.9}$ \\
\hline \multicolumn{5}{|c|}{ D.s. of the cl. Digitario sanguinalis-Eragrostietea minoris } \\
\hline Setaria pumila & 8 & $33^{36.7}$ & 4 & 5 \\
\hline \multicolumn{5}{|c|}{ D.s. of the cl. Molinio-Arrhenatheretea } \\
\hline Achillea millefolium & 62 & $83^{13}$ & $76^{3.4}$ & 73 \\
\hline Taraxacum officinale & 38 & 33 & $64^{13.7}$ & $73^{23.8}$ \\
\hline Trifolium pratense & 38 & $67^{24}$ & $56^{11.6}$ & 23 \\
\hline Centaurea jacea & $23^{13.2}$ & $17^{2.8}$ & $20^{8.2}$ & . \\
\hline Vicia cracca & 8 & . & $40^{22.8}$ & $45^{30.3}$ \\
\hline Poa pratensis & $31^{23.9}$ & . & $32^{25.9}$ & . \\
\hline Trifolium hybridum & . & . & $32^{41.3}$ & 9 \\
\hline Rumex crispus & 8 & . & 8 & $27^{30.8}$ \\
\hline \multicolumn{5}{|l|}{ Other species } \\
\hline Medicago falcata & $31^{13.6}$ & 17 & $28^{9.7}$ & 9 \\
\hline Artemisia campestris & $23^{25.5}$ & . & $12^{4}$ & 5 \\
\hline Medicago lupulina & 15 & . & $36^{30.9}$ & 14 \\
\hline Rubus caesius & $23^{42.9}$ & . & . & . \\
\hline Carex hirta & . & $33^{47.6}$ & 4 & . \\
\hline Plantago major & . & . & $16^{7.2}$ & $32^{35.3}$ \\
\hline Leonurus quinquelobatus & . & . & . & $23^{42.5}$ \\
\hline
\end{tabular}

Communities of the association are widespread in the temperate zone of Europe and have been identified in many countries (Mucina 1981; Solomakha et al. 1992; Pott 1995; Dierßen 1996; Jarolímek et al. 1997; Sanda et al. 1999; Motiekaityté 2001; Schubert 2001; Borhidi 2003; Matuszkiewicz 2007; Chytrý 2009; Kulikova 2012). In Russia, phytocoenoses with Melilotus officinalis and $M$. albus are described as the ass. Melilotetum albo-officinalis or basal communities with one of the two Melilotus species being dominant (Ishbirdin et al. 1988; Govorov 2004; Bulokhov \& Kharin 2008; Arepieva 2015, 2017; Golovanov \& Abramova 2012; Bagrikova 2016; Golovanov et al. 2017). Melilotus officinalis and M. albus, and occasionally with some others, are listed in various sources as diagnostic species of the association.

In some regions of Europe, relevés have been differentiated and the association is divided into subassociations and variants, which most often correspond to different succession stages of the vegetation (Jarolímek et al. 1997; Motiekaityté 2001, Sanda et al. 2008; Chytrý 2009). 
In Russia and the neighboring regions, variants of this association were established only for the city of Kursk (Arepieva 2015, 2017). In this paper, the differentiation of relevés of the association is carried out, and subassociations and variants are established. Their floristic composition reflects ecological and geographical features of communities in forest, forest-steppe and steppe zones of the European part of Russia and Belarus.

Three subassociations are distinguished within the association.

Subass. typicum Passarge 1977 (Tab. 2, syntaxa 1, 2; Tab. 3) includes typical communities of the association. Diagnostic species are Melilotus albus and $M$. officinalis. Phytocoenoses of this subassociation are described in the Kursk region and in the cities of Bryansk and Minsk.

Subass. typicum includes two variants.

Var. typica (Tab. 2, syntaxon 1; Tab. 3, relevés 1-13) includes the most typical communities. Diagnostic species are Melilotus albus and $M$. officinalis. Such communities often contain few species due to the strong dominance of the diagnostic species. 90 species were recorded in the syntaxon. The number of species per relevé is 6-27. Phytocoenoses of the variant are described in the Kursk region and in the cities of Bryansk and Minsk.

Var. Ambrosia artemisiifolia (Tab. 2, syntaxon 2; Tab. 3, relevés 14-19). Diagnostic species of the variant are Ambrosia artemisiifolia, Xanthium albinum, Lotus corniculatus, Oenothera rubricaulis, Lactuca serriola, Acer negundo, Setaria viridis, Centaurea pseudomaculosa, Eragrostis minor. The herb layer usually is not closed (30-55\%). 48 species are registered in the variant. The number of species per relevé is 18-28. The communities are formed on the gravelly substrate of railway embankments and nearby sites. They are regularly disturbed during railway repairs and herbicide treatment and are at the earlier stage in succession series compare to the var. typica, that's why species of classes Sisymbrietea Gutte et Hilbig 1975 and Digitario sanguinalis-Eragrostietea minoris Mucina, Lososová et Šilc in Mucina et al. 2016 (Ambrosia artemisiifolia, Chenopodium album, Lactuca serriola, Setaria pumila, $S$. viridis) are more common there. These phytocoenoses are described in the city Kursk (Arepieva 2017, 2019).

Subass. Melilotetum albo-officinalis tussilaginetosum farfarae Jarolímek et al. 1997 (Tab. 2, syntaxon 3; Tab. 4, relevés 1-25). Diagnostic species are Dactylis glomerata, Festuca pratensis, Daucus carota, Phleum pratense, Agrostis gigantea, Tussilago farfara. This subassociation includes the most mesophytic communities of the association. In most cases, Melilotus albus is the dominant species. Meadow species of the class Molinio-Arrhenatheretea Tx. 1937 (Agrostis gigantea, Dactylis glomerata, Festuca pratensis, Phleum pratense, Trifolium pratense) are present in the coenoflora with high constancy. The total plant cover is $50-100 \%$. The number of species per relevé is 6-34. In total, there are 124 species in the coenoflora. Phytocoenoses of the subassociation are formed mainly on moderately moist soils and substrates and are common in wastelands, near buildings, along the banks of 
reservoirs. They are described in the cities of Minsk and Bryansk and in the Kursk region.

Subass. Melilotetum albo-officinalis carduetosum acanthoidis subass. nov. hoc loco (Tab. 2, syntaxon 4; Tab. 4, relevés 26-47), nomenclature type (holotypus hoc loco) - relevé 41 (R14); Russian Federation, Republic of Bashkortostan, the town of Salavat, 116th quarter, sites along the heat pipeline, $0.8 \mathrm{~km}$ south of the Sadovaya street, 26.06.2009, author of relevé - Ya. M. Golovanov. Diagnostic species are Carduus acanthoides, Arctium tomentosum, Linaria vulgaris, Pastinaca sativa. In communities of this subassociation, Melilotus officinalis is most often present with the highest cover. The floristic composition is characterized by a high share of xeromesophytes of the order Onopordetalia acanthii and the alliance DaucoMelilotion (Berteroa incana, Carduus acanthoides, Echium vulgare, Euphorbia virgata, Linaria vulgaris, Picris hieracioides, Potentilla argentea). The total plant cover is $50-90 \%$. The number of species per relevé is $12-39$. In the subassociation, 98 species were registered. Phytocoenoses can be found on dry soils and substrates, on the slopes of railway embankments, in wastelands, ruderal grassplots. They are described in steppe and forest-steppe zones of the European part of Russia (the Republic of Bashkortostan, the Kursk region).

The minimum number of species per releve for the association was recorded in the subass. typicum var. typica and in the subass. tussilaginetosum farfarae -6 species. The maximum number of species (39) was noted in the subass. carduetosum acanthoidis. The lowest plant cover (30\%) was observed in the subass. typicum var. Ambrosia artemisiifolia, the highest plant cover (100\%) was recorded in the subass. typicum var. typica and in the subass. tussilaginetosum farfarae.

Differences in the floristic composition of the described subassociations and variants are determined by the ecological conditions of communities. Fig. 2 represents the ranges of values of the ecological characteristics of their habitats. Tab. 5 shows that the studied phytocoenoses differ more in the levels of moisture in soils and substrates, temperature, continentality and hemeroby, while the differences in the values of acidity, richness in mineral nitrogen, light are less pronounced. DCA-ordination of relevés by ecological factors (Fig. 3.) shows similar results. It is logical that mesophyte-rich communities of the subass. tussilaginetosum farfarae are often formed on wetter soils and substrates, and xeromesophytes-rich communities of the subass. carduetosum acanthoidis are more common in the dryest ones. These subassociations differ most in terms of climate continentality and light, too. Communities of the var. Ambrosia artemisiifolia are characterized by the highest value of temperature and the level of hemeroby reflecting the degree of anthropogenic pressure on the phytocoenoses. This is determined by their occurrence on railway embankments and nearby sites in periodically disturbed habitats. 
Tab. 3 Phytocoenotic table of the subass. Melilotetum albo-officinalis typicum, var. typica and var. Ambrosia artemisiifolia.

\begin{tabular}{|c|c|c|c|c|c|c|c|c|c|c|c|c|c|c|c|c|c|c|c|c|c|}
\hline \multirow{2}{*}{$\begin{array}{l}\text { Variants } \\
\text { Plant cover, \% }\end{array}$} & \multicolumn{14}{|c|}{ typica } & \multicolumn{7}{|c|}{$\begin{array}{c}\text { Ambrosia } \\
\text { artemisiifolia }\end{array}$} \\
\hline & & & 응 & 악 & ถึ & ○ & পి & 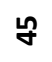 & 으 & $\stackrel{ }{\wedge}$ & ㅇ & ○ & $\stackrel{ }{\wedge}$ & & 요 & ก็ & 움 & 유 & ஸि & 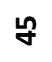 & \\
\hline Number of species & $\stackrel{-1}{-1}$ & & $\bullet$ & 오 & $\stackrel{n}{\sim}$ & $\underset{\sim}{\sim}$ & $\mathbf{N}$ & f & 站 & 욱 & 욱 & $\underset{7}{\sim}$ & $\stackrel{\bullet}{\sim}$ & & 亗 & $\stackrel{9}{r}$ & $\stackrel{\infty}{\rightarrow}$ & $\stackrel{\infty}{N}$ & $\ddot{N}$ & $\stackrel{m}{N}$ & \\
\hline Localities of relevés* & $\ddot{m}$ & $\ddot{\infty}$ & $\stackrel{\nabla}{\Sigma}$ & 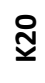 & $\underset{N}{N}$ & $\underset{\vec{F}}{ت}$ & $\stackrel{\infty}{\underline{\infty}}$ & $\underset{\sim}{\check{Y}}$ & $\stackrel{m}{\vec{y}}$ & $\underset{\infty}{\vec{D}}$ & ஜิ & 음 & $\underset{\infty}{\stackrel{N}{\infty}}$ & & $\underline{\simeq}$ & $\underline{m}$ & $\mathbb{Z}$ & $\stackrel{\text { ㅁ }}{\underline{y}}$ & $\underline{\underline{ }}$ & $\underline{\nabla}$ & \\
\hline Number in table & $-r$ & $N$ & $m$ & $\theta$ & n & 6 & $\sim$ & $\infty$ & $\sigma$ & 억 & $ت$ & $\underset{\sim}{\sim}$ & $\stackrel{m}{r}$ & C & $\underset{+}{+}$ & $\stackrel{n}{\sim}$ & $\underset{-}{\sigma}$ & $A$ & $\stackrel{\infty}{\sim}$ & 암 & C \\
\hline \multicolumn{22}{|c|}{ D. s. of the ass. Melilotetum albo-officinalis, subass. typicum and var. typica } \\
\hline Melilotus officinalis & & . & . & . & . & 2 & 4 & 3 & 3 & 4 & 4 & 5 & 4 & IV & + & 2 & + & $r$ & 2 & + & V \\
\hline Melilotus albus & 5 & 3 & 4 & 5 & 3 & 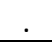 & . & . & . & . & . & . & . & II & 2 & 2 & 2 & 2 & . & + & V \\
\hline \multicolumn{22}{|c|}{ D. s. of the var. Ambrosia artemisiifolia } \\
\hline Ambrosia artemisiifolia & . & . & . & . & . & . & . & . & . & . & . & . & . & . & + & + & 1 & 1 & + & + & V \\
\hline Xanthium albinum & . & . & . & . & . & . & . & . & . & . & . & . & . & . & + & + & + & 1 & + & 1 & V \\
\hline Lotus corniculatus & + & . & . & . & . & . & . & . & . & . & . & . & . & I & 2 & + & + & + & $r$ & + & V \\
\hline Oenothera rubricaulis & . & . & . & . & r & . & . & . & . & . & . & . & . & I & $r$ & 1 & + & . & + & $r$ & V \\
\hline rriola & . & . & . & . & . & . & . & . & . & . & . & . & . & . & . & $r$ & + & $r$ & + & $r$ & V \\
\hline Acer negundo & . & . & . & . & $r$ & . & . & . & . & . & . & . & . & I & + & . & $r$ & $r$ & 1 & . & IV \\
\hline Centaurea pseudomaculosa & . & . & . & . & . & . & . & . & . & . & . & . & . & . & $r$ & . & . & $r$ & + & . & III \\
\hline Setaria viridis & . & . & . & . & . & . & . & . & . & . & . & . & . & - & . & $r$ & . & + & . & + & III \\
\hline Eragrostis minor & . & . & . & . & . & . & . & . & . & . & . & . & . & . & . & . & . & 1 & . & + & II \\
\hline \multicolumn{22}{|c|}{ D.s. of the all. Dauco-Melilotion and ord. Onopordetalia acanthii } \\
\hline Artemisia absinthium & . & + & . & . & $r$ & $r$ & 2 & + & . & + & + & + & + & IV & $r$ & + & . & + & $r$ & . & IV \\
\hline Cichorium intybus & + & + & . & . & r & . & . & . & . & + & . & . & + & II & $r$ & $r$ & . & $r$ & + & . & IV \\
\hline Echium vulgare & . & . & . & . & . & . & 1 & $r$ & . & . & . & . & . & $\mathbf{I}$ & $r$ & $r$ & . & . & $r$ & $r$ & IV \\
\hline Tanacetum vulgare & . & . & . & . & . & + & $r$ & + & + & . & . & . & . & II & + & . & . & $r$ & . & . & II \\
\hline Berteroa incana & . & . & . & . & . & . & . & + & $r$ & + & + & + & . & II & . & . & . & . & + & . & I \\
\hline Linaria vulgaris & 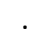 & . & . & . & . & . & . & . & $r$ & . & . & . & . & I & . & . & . & $r$ & + & . & II \\
\hline Euphorbia virgata & . & + & . & . & . & . & . & . & $r$ & . & . & + & . & II & . & . & . & . & . & . & . \\
\hline Verbascum lychnitis & $\cdot$ & . & . & . & . & $r$ & . & . & $\mathrm{r}$ & . & . & . & . & $\mathbf{I}$ & . & . & . & . & r & . & $\mathbf{I}$ \\
\hline \multicolumn{22}{|c|}{ D.s. of the ord. Agropyretalia intermedio-repentis } \\
\hline Elytrigia repens & & 1 & 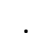 & . & 1 & + & 2 & + & . & 2 & 1 & 1 & + & IV & + & + & + & + & + & 2 & V \\
\hline Convolvulus arvensis & + & 1 & . & 1 & . & 1 & . & . & + & . & . & + & + & III & + & + & + & 1 & + & 2 & V \\
\hline Calamagrostis epigeios & + & . & 2 & 1 & . & + & . & . & . & . & . & . & + & II & $r$ & $r$ & + & $r$ & . & . & IV \\
\hline Poa compressa & . & . & . & . & 1 & 2 & . & 1 & + & . & . & . & . & II & + & $r$ & . & + & + & 1 & V \\
\hline Poa angustifolia & $\cdot$ & . & . & 2 & . & . & . & + & . & . & . & . & . & $\mathbf{I}$ & . & . & . & $\mathrm{r}$ & . & . & I \\
\hline \multicolumn{22}{|c|}{ D.s. of the cl. Artemisietea vulgaris } \\
\hline Artemisia vulgaris & 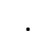 & 1 & 2 & $r$ & $r$ & . & 2 & r & . & + & . & . & . & III & $r$ & . & $r$ & + & + & . & IV \\
\hline Cirsium arvense & + & + & . & + & . & . & . & . & . & . & . & . & + & II & . & . & r & . & . & . & I \\
\hline Erigeron annuus & . & . & 1 & $r$ & . & + & + & . & . & + & + & + & . & III & . & . & . & . & . & . & . \\
\hline \multicolumn{22}{|l|}{ D.s. of the cl. Sisymbrietea } \\
\hline Erigeron canadensis & $\cdot$ & & $\cdot$ & 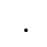 & . & . & + & . & 1 & . & . & . & . & I & + & . & . & $r$ & . & $r$ & III \\
\hline Chenopodium album & . & . & $\cdot$ & . & . & & 1 & . & . & . & . & . & . & I & . & . & . & $r$ & $r$ & + & III \\
\hline Sisymbrium loeselii & . & . & . & . & . & r & . & + & . & . & . & . & . & $\mathbf{I}$ & + & . & . & . & 2 & . & II \\
\hline Lactuca tatarica & & & . & . & . & . & . & . & + & . & . & . & . & I & + & . & . & . & + & . & II \\
\hline Senecio vulgaris & + & + & . & . & . & . & . & . & . & . & . & . & + & II & . & . & . & . & . & . & . \\
\hline
\end{tabular}


Tab. 3 - cont.

\begin{tabular}{|c|c|c|c|c|c|c|c|c|c|c|c|c|c|c|c|c|c|c|c|c|c|}
\hline Number in tabl. & $r$ & $N$ & m & $\theta$ & in & $\bullet$ & $\Lambda$ & $\infty$ & $\sigma$ & 욱 & $\underset{-}{-}$ & ㄱ & $\stackrel{m}{r}$ & C & $\underset{-}{\Delta}$ & 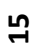 & $\stackrel{\bullet}{\bullet}$ & ન & $\stackrel{\infty}{\rightarrow}$ & 각 & C \\
\hline \multicolumn{22}{|c|}{ D.s. of the cl. Digitario sanguinalis-Eragrostietea minoris } \\
\hline Setaria pumila & $\cdot$ & . & • & $\cdot$ & . & $\theta^{\circ}$ & + & $\cdot$ & . & . & . & . & . & $\mathbf{I}$ & $0^{\circ}$ & . & . & r & $r$ & & II \\
\hline Plantago indica &. & . & . & . & . & . & . & . & . & . & + & + & . & $\mathbf{I}$ & . & r & . & . & . & . & $\mathbf{I}$ \\
\hline \multicolumn{22}{|c|}{ D.s. of the cl. Molinio-Arrhenatheretea } \\
\hline Achillea millefolium & r & + & . & + & + & + & . & . & + & . & . & + & + & IV & r & . & $r$ & + & r & r & $\mathbf{V}$ \\
\hline Trifolium pratense & . & . & 2 & 1 & + & . & $r$ & . & . & . & + & . & . & II & r & $r$ & r & . & . & $r$ & IV \\
\hline Taraxacum officinale & . & + & 2 & + & . & . & . & + & + & . & . & . & . & II & $r$ & . & . & . & . & $r$ & II \\
\hline Centaurea jacea & + & . & . & . & . & . & . & + & . & . & . & . & + & II & . & . & . & . & . & $r$ & I \\
\hline Poa pratensis & . & + & . & . & . & . & . & . & . & + & 1 & + & . & II & . & . & . & . & . & . & . \\
\hline \multicolumn{22}{|l|}{ Other species } \\
\hline Medicago falcata & $\cdot$ & . & $\cdot$ & + & . & $\theta^{\circ}$ & 1 & + & 1 & . & . & . & . & II & $\theta^{\circ}$ & . & $r$ & . & . & . & I \\
\hline Artemisia campestris & . & . & . & . & . & . & . & . & + & . & + & + & . & II & . & . & . & . & . & . & . \\
\hline Rubus caesius & . & . & . & . & . & . & . & . & . & + & $r$ & + & . & II & . & . & . & . & . & . & $\dot{\theta}$ \\
\hline
\end{tabular}

Taxa in one or two relevés: Agrimonia eupatoria $4(r)$, Anisantha tectorum 17 ( $r$ ), Anthemis tinctoria $13(+)$, Anthriscus sylvestris $2(+)$, Arctium tomentosum 2(+), Artemisia austriaca $9(1)$, Astragalus cicer $13(+)$, Atriplex sagittata $7(\mathrm{r})$, Bromopsis inermis $8(+)$, Bromus japonicus $7(\mathrm{r})$, Bunias orientalis $2(+)$, Capsella bursa-pastoris $7(r)$, Carduus acanthoides $17(r)$, Carex hirta $14(2)$, 19 (1), Carum carvi $1(+)$, Centaurea scabiosa $9(+)$, Chenopodium rubrum $15(r)$, Cirsium polonicum $9(+)$, Consolida regalis $7(r)$, Corispermum hyssopifolium $17(+)$, Crepis tectorum $9(+)$, Cyclachaena xanthiifolia $7(r)$, Dactylis glomerata $7(r), 10(1)$, Daucus carota $4(r), 5(r)$, Elaeagnus angustifolia $5(r)$, Equisetum arvense $4(r), 15(1)$, Erigeron acris $8(r)$, Fallopia convolvulus $8(r), 19(+), F$. dumetorum $9(r)$, Festuca pratensis $7(r)$, Fragaria viridis $2(+)$, Galeopsis bifida $7(r)$, Galium mollugo $2(+), 7(r)$, Geranium pratense $2(+)$, G. sibiricum $2(+)$, Jacobaea vulgaris $9(+)$, Knautia arvensis $7(r)$, Lappula squarrosa $9(+)$, Linum usitatissimum $9(r)$, Medicago lupulina $4(+), 7(1)$, Melandrium album $6(+)$, Mentha longifolia $2(+)$, Oenothera biennis $17(1)$, Onopordum acanthium $13(+)$, Pastinaca sativa 1(+), $4(r)$, Picris hieracioides $14(+), 16(r)$, Pilosella officinarum $9(r)$, Polygonum aviculare $19(\mathrm{r})$, Populus sp. $5(+), 16(\mathrm{r})$, Potentilla argentea $7(+), 9(\mathrm{r})$, Ranunculus polyanthemos $13(+)$, Rorippa austriaca $19(+)$, Rumex crispus $7(\mathrm{r})$, Salix sp. $13(+)$, S. triandra 5 $(\mathrm{r})$, Salvia verticillata $8(+)$, Sisymbrium officinale $9(+)$, S. volgense $4(1)$, Trifolium aureum $4(+)$, Tripleurospermum inodorum 5 (1), 7 (1), Stellaria graminea 13 (+), Veronica chamaedrys 4 (1), Vicia cracca 4 (1). *Localities of relevés: see the note for Tab. 4.

\section{Discussion}

The established syntaxa reflect not only different ecological conditions of communities, but also some geographical distribution features due to the location of the research areas in different natural zones (forest, forest-steppe, steppe) and changes in the climate continentality on the territory.

Most of the relevés classified in the subass. typicum var. typica were made in the western part of the study area (the city of Bryansk, the Kursk region). These communities cannot be assigned to the subass. tussilaginetosum farfarae or the subass. carduetosum acanthoidis because the species composition places them in a transitional position between these two subassociation. Often they are depauperated due to strong dominance. Such communities are often mentioned in literature, but they are not considered a variant typica (Chytrý 2009). 
Tab. 4 Phytocoenotic table of the subass. Melilotetum albo-officinalis tussilaginetosum farfarae and carduetosum acanthoidis.

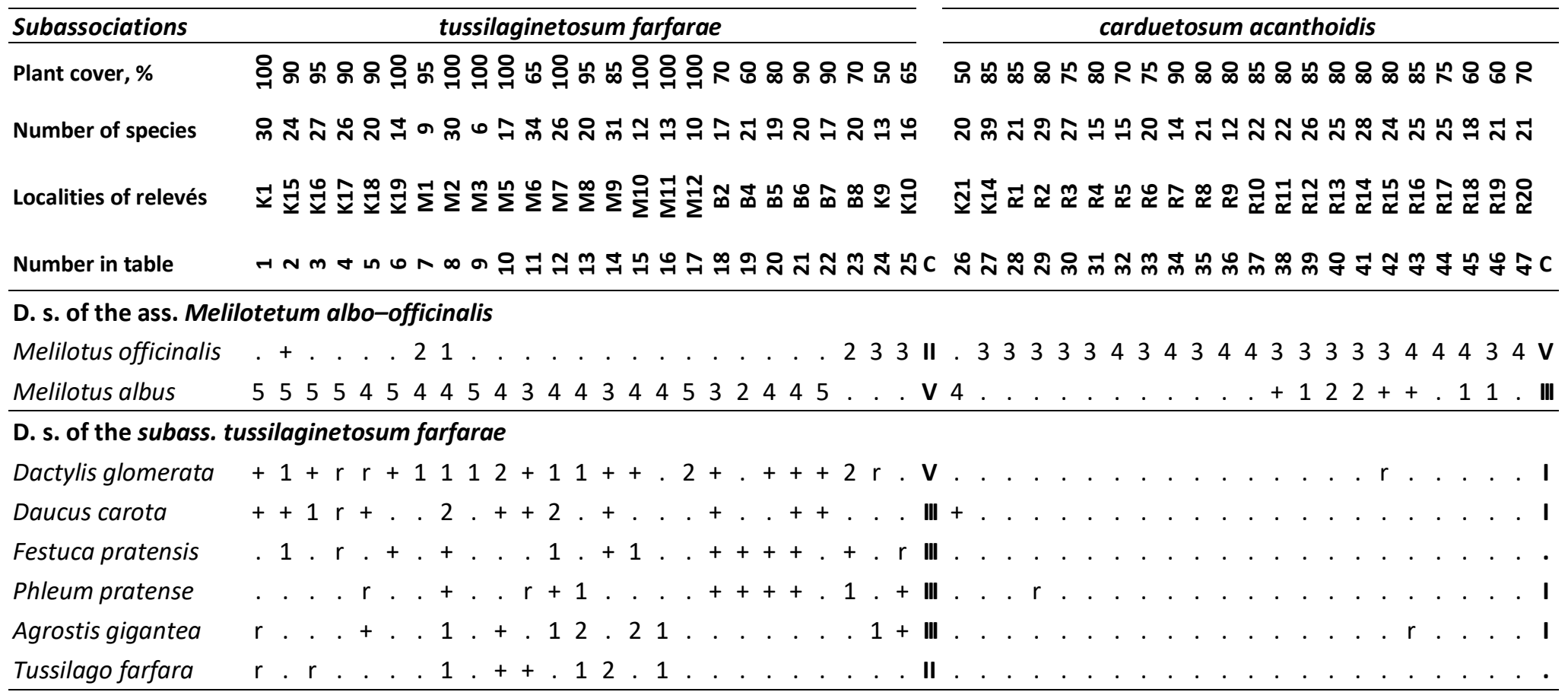

D. s. of the subass. carduetosum acanthoidis

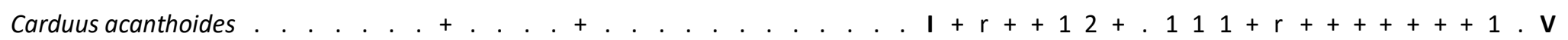

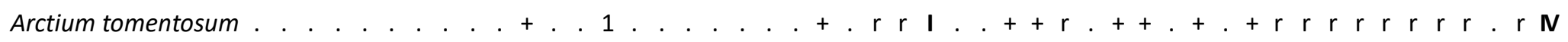

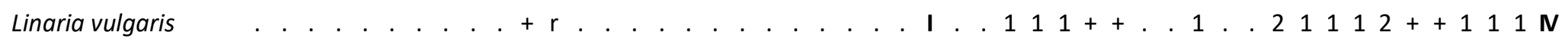


Tab. 4 - cont.

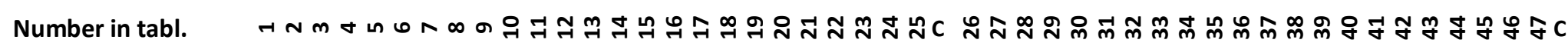

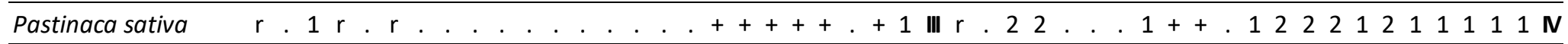

\section{D.s. of the all. Dauco-Melilotion and ord. Onopordetalia acanthii}

Artemisia

absinthium

Cichorium intybus

Echium vulgare

Euphorbia virgata

Berteroa incana

Tanacetum vulgare

Picris hieracioides

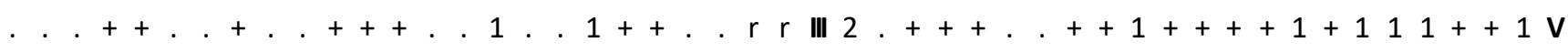

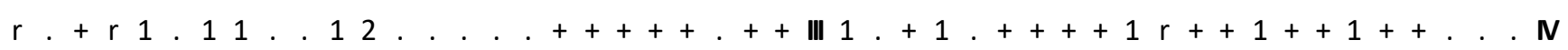

. $r . r 1$. . . . . . . . . . . . . . . . . I $2+.++1.1+.+++++++1+. .2$

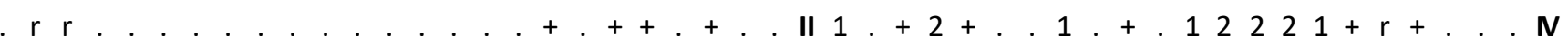

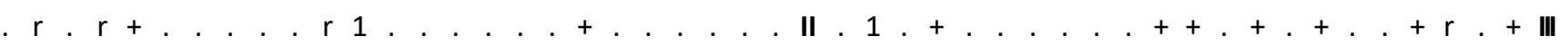

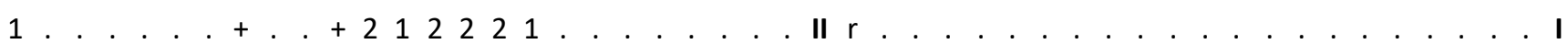

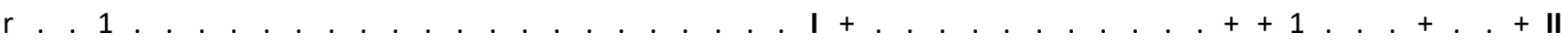

$\Vdash \quad$ Potentilla argentea

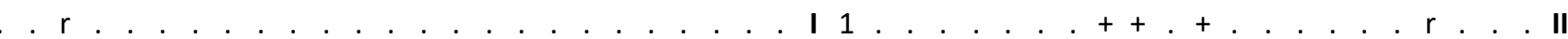

Cynoglossum

officinale

Tragopogon dubius

.. . . . . . . . . . . . . . . . . . . . . . r....... . . $1+$ II

Lappula squarrosa

D.s. of the ord. Agropyretalia intermedio-repentis

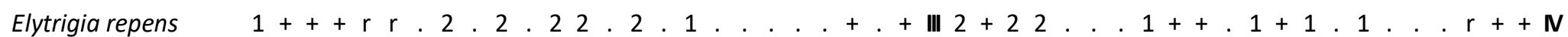

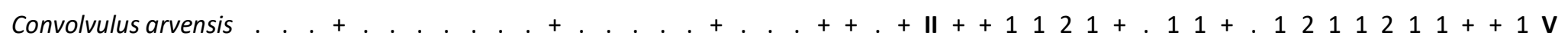

Poa compressa

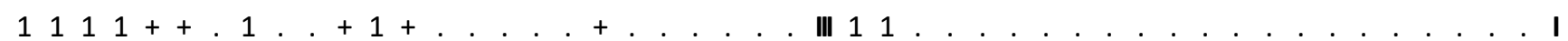

Poa angustifolia

. 1.1

I. $1++. . . . .+++.1$. 1 + 11 . . . $r$. III

Bromopsis inermis

12 . . . . . . I. . . . . r. . $1.1+1+. r . .+$ II 
Tab. 4 - cont.

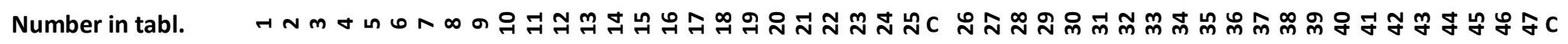

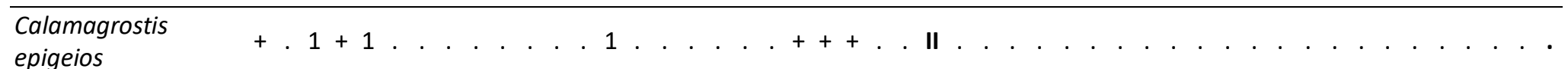
epigeios

D.s. of the cl. Artemisietea vulgaris

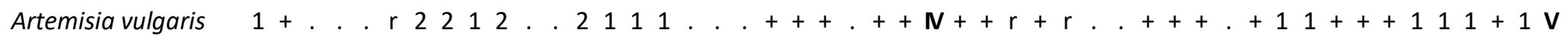

Cirsiumarvense $1 . r . . . .2 .22 . .11 .2 . .+\ldots+. . . \|+.1221++++\ldots+. . . r+11+1 \mathbf{N}$

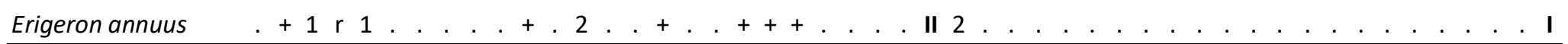

D.s. of the cl. Sisymbrietea

Tripleurospermum

inodorum

Sisymbrium loeselii

Lactuca serriola

++ . . . . .

$2+++1$

$\|1 \ldots+1+\ldots+\ldots . . .+1+++. r 1+\|$

Sonchus arvensis

Atriplex sagittata

Erigeron canadensis . . . . . . . . 1 . . . . . . . . . . . I +. . 1 . . . . . 1......... I

. $r$

$\mathbf{I}+$

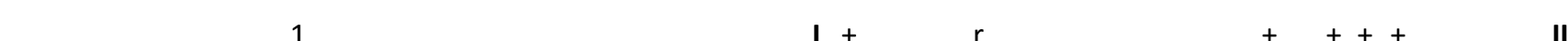

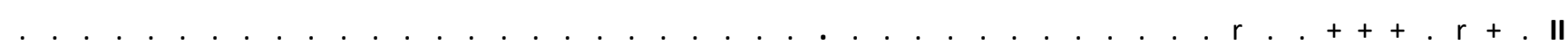

+ . . . . . . . . . . . . . I r. . . . . . . . . . . . I

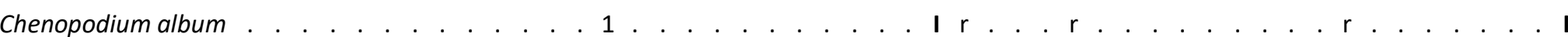

Atriplex tatarica . . . . . . . . . . . . . . . . . . . . . . . . . . . . + + . 1 1 ............. I

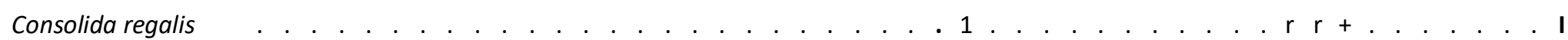

Capsella bursa-

pastoris

Lactuca tatarica

$1 .+.+. .+r$ I 
Tab. 4- cont.

Number in tabl. $\quad$ Nmナル

\section{D.s. of the cl. Molinio-Arrhenatheretea}

Achillea millefolium +. . . 1 r 1111112 . + $2.2+$. + + + + + r N $1+++$. . + + $1.1+$. $11 .+++1+\mathbf{N}$

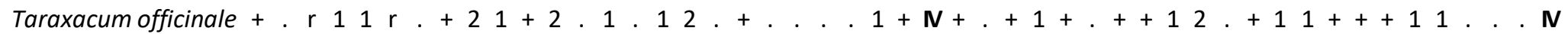

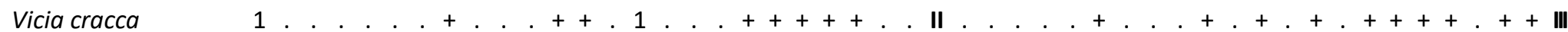

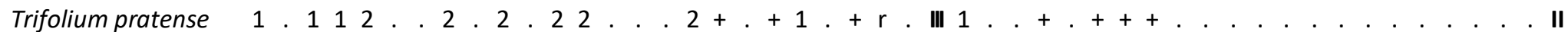

Trifolium hybridum . . . . . . 2. . 21 . 1... . $r+++.$. II..... . . . . . . . . . . . . .

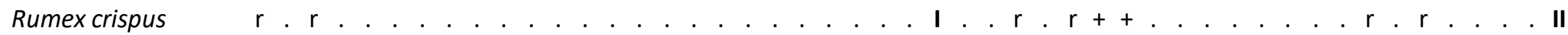

Poa pratensis $\quad$. . . . . . . $1.1+2$. . . . . . $1+1$. +. . II. . . . . . . . . . . . . . . . . . . . . .

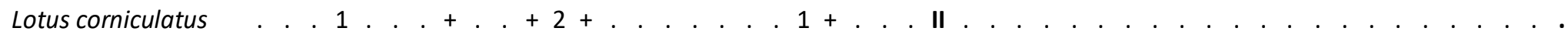

Leontodon

autumnalis

Centaurea jacea

Festuca arundinacea

Galium mollugo

Carum carvi

\section{Other species}

Medicago falcata

Medicago lupulina

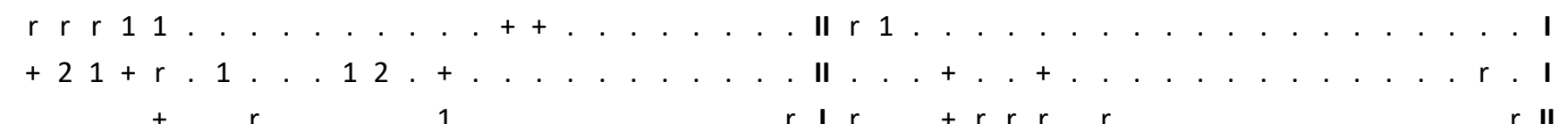

Plantago major

Leonurus

quinquelobatus

Melandrium album

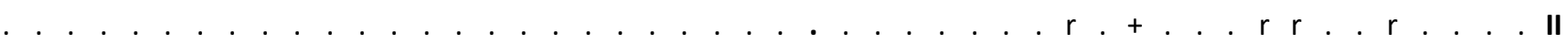


Tab. 4 - cont.

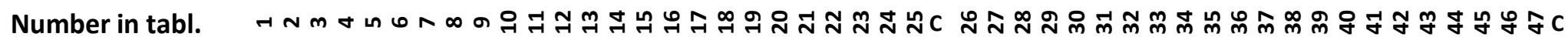

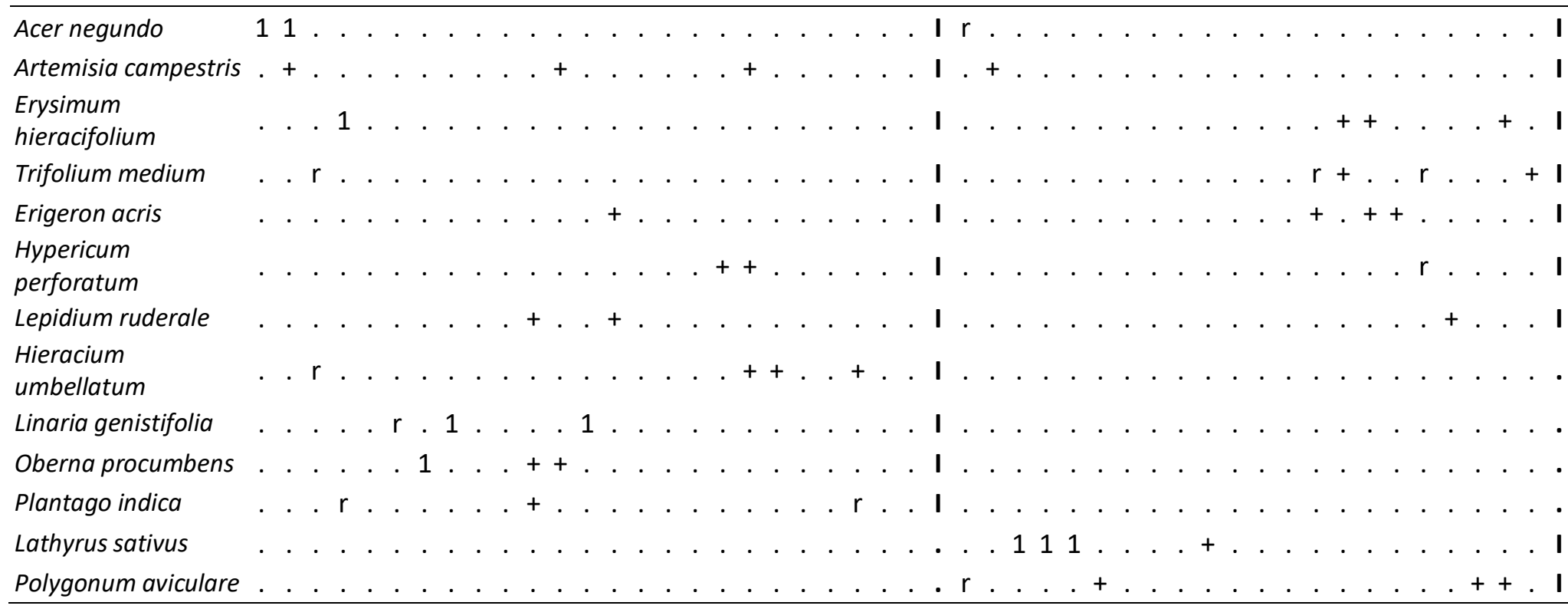


Taxa in one or two relevés: Agrimonia eupatoria $8(+), 13(+)$, Agrostis tenuis $8(1), 11(r)$, Ambrosia artemisiifolia 1 (2), Anisantha tectorum 2 (+), 30 (r), Arctium lappa 8 (1), 9 (2), Arenaria serpyllifolia $30(+)$, Armoracia rusticana $1(r)$, Arrhenatherum elatius 1 ( $r), 3(2)$, Artemisia sieversiana 33 (1), Astragalus cicer 35 (1), $37(+)$, Bassia scoparia 35 (r), Bidens frondosa $1(r)$, Brassica campestris $42(r)$, Bromus arvensis $4(r), B$. commutatus $3(r), B$. japonicus $1(1), 2(2)$, B. mollis $2(+), 11(+), B$ squarrosus $29(+)$, Bunias orientalis $22(r)$, Campanula rapunculoides $23(+)$, Carex contigua $12(+)$, C. hirta $18(+)$, C. muricata $23(1)$, Centaurea pseudomaculosa $2(r), 27(r)$, C. scabiosa $27(+)$, Cerastium holosteoides $11(+)$, Cirsium polonicum $25(+)$, Conium maculatum $40(r)$, Crepis tectorum $29(r), 47(r)$, Dipsacus sylvestris $3(+)$, Dracocephalum thymiflorum $30(+), 36(+)$, Equisetum arvense $11(1), 14(+)$, Erysimum cheiranthoides $36(r)$, Euphrasia stricta $27(r)$, Falcaria vulgaris $3(r), 26(1)$, Fallopia convolvulus $26(r), 44(r)$, Festuca rubra $8(1), 13(1)$, F. trachyphylla $18(+)$, F. valesiaca $12(2)$, Geranium pratense $13(+), 16(1)$, G. sibiricum 24 (r), 25 (r), Geum urbanum $14(1)$, Helianthus tuberosus 19 (1), Knautia arvensis 15 (1), Lathyrus pratensis 26 (r), L. tuberosus 37 (r), $42(+)$, Lavatera thuringiaca $11(\mathrm{r})$, Lepidium densiflorum $19(+)$, Leucanthemum vulgare $14(+)$, Lycopsis arvensis $28(2), 29(+)$, Lolium perenne $10(+)$, Lonicera tatarica 41 (1), Lupinus polyphyllus $30(\mathrm{r})$, Matricaria matricarioides $26(+)$, Medicago sativa $13(1)$, Nonea pulla 29 $(r), N$. rossica $46(r)$, Oenothera biennis $27(r)$, O. rubricaulis $2(+)$, Origanum vulgare $18(1)$, Plantago lanceolata $14(+)$, Poa palustris $3(1)$, Populus tremula $6(\mathrm{r}), 11(+)$, Potentilla erecta $11(+)$, Puccinellia distans $18(+)$, Ranunculus acris $10(\mathrm{r})$, R. polyanthemos $23(+)$, Rorippa austriaca $37(+)$, Rumex acetosa $7(+), 14(+), R$. thyrsiflorus $14(1)$, Salix dasyclados $14(+)$, Saponaria officinalis $23(+)$, Senecio vulgaris $19(+), 23(1)$, Seseli libanotis $30(+)$, Setaria pumila $1(r), 26(+)$, S. viridis $26(+)$, Silene noctiflora $10(+)$, Solidago canadensis $27(r)$, Sorbus aucuparia $3(r), 21(+)$, Tanacetum corymbosum $37(r)$, Thesium arvense $30(r)$, Trifolium arvense $20(1), T$. fragiferum $6(+), T$. repens $6(+)$, Urtica dioica $14(+), 26(r)$, Verbascum densiflorum $1(1)$, V. lychnitis $27(+)$, Vicia hirsuta $22(+)$, V. sepium $3(1)$, V. tetrasperma 27 (r), Viola arvensis $30(+)$, Xanthium albinum $30(r), 31(r)$.

Localities and number of relevés:

B - Bryansk and suburban area, $\mathrm{K}$ - Kursk region, $\mathrm{M}$ - Minsk, $\mathrm{R}$ - Republic of Bashkortostan. Bryansk and suburban area

B1, B3 - Suponevo settlement, right slope of the Desna river valley, $30 \mathrm{~m}^{2}, 10 \mathrm{~m}^{2}, 53.202058$, 34.323536 (22.07.2004), author of relevés - A. V. Kharin;

B2, B4 - abandoned suburban areas, $0.2 \mathrm{~km}$ east of the public transport stop "Telecentre", $100 \mathrm{~m}^{2}, 120 \mathrm{~m}^{2}, 53.202058,34.323536$ (27.07.2004), author of relevés - A. D. Bulokhov;

B5, B6 - Balakhonovka village, the bottom of an abandoned quarry, $0.3 \mathrm{~km}$ southeast of the dacha plots, $10 \mathrm{~m}^{2}, 14 \mathrm{~m}^{2}, 53.220054,34.311660$ (27.07.2004), author of relevés - A. D. Bulokhov;

B7 - roadside near the public transport stop "Telecentre", $7 \mathrm{~m}^{2}, 53.220605,34.318130$ (27.07.2004), author of relevé - A. D. Bulokhov;

B8 - slope of the dam, ravine "Verkhniy Sudok", 40 m², 53.246916, 34.368434 (24.06.2004), author of relevé - A. V. Kharin;

B9 - slope of the ravine "Nizhniy Sudok" behind the youth center "Fortuna", $50 \mathrm{~m}^{2}$, 53.240287, 34.360400 (10.07.2004), author of relevé - A. V. Kharin;

B10, B11 - slope of the dam, ravine "Nizhniy Sudok", $10 \mathrm{~m}^{2}, 6 \mathrm{~m}^{2}, 53.239850,34.360292$ (10.07.2004); author of relevés - A. V. Kharin;

B12 - slope of the Desna river valley in the area of the Svensky monastery, $14 \mathrm{~m}^{2}, 53.205131$, 34.330405 (22.07. 2004); author of relevé - A. V. Kharin;

Kursk region. Author of relevés - L. A. Arepieva 
K1 - Kursk, grass plot on Ponyrovskaya street near garages under construction, $15 \mathrm{~m}^{2}$, 51.786749, 36.181382 (16.08.2016);

K2 - Kursk, plot near the railway line, $0.5 \mathrm{~km}$ north of the station, $36 \mathrm{~m}^{2}, 51.751901$, 36.228753 (28.07.2009);

K3 - Kursk, plot near the railway line, $0.8 \mathrm{~km}$ north of the station, $9 \mathrm{~m}^{2}, 51.757387,36.231682$ (28.07.2009);

K4 - Kursk, embankment of rubble near the railway line, $0.5 \mathrm{~km}$ north of the station, $16 \mathrm{~m}^{2}$, 51.751901, 36.228753 (28.07.2009) (28.07.2009);

K5 - Kursk, plot on the tracks of an unused railway line, $0.8 \mathrm{~km}$ north of the station, $16 \mathrm{~m}^{2}$ 51.757387, 36.231682 (28.07.2009);

K6 - Kursk, building rubble at the bottom of the pit near the railway line, $0.5 \mathrm{~km}$ north of the station, $16 \mathrm{~m}^{2}$ 51.751901, 36.228753 (28.07.2009);

K7 - Kursk, plot on the tracks of an unused railway line, $1.2 \mathrm{~km}$ north of the station, $16 \mathrm{~m}^{2}$, 51.760608, 36.233429 (28.07.2009);

K8 - urban settlement Ponyri, roadside of Sapunov street in front of the house no. 84, $16 \mathrm{~m}^{2}$, 52.320989, 36.310835 (20.08.2016);

K9, K10 - Kursk, wastelands on Kommunisticheskaya street near the Kur river, $6 \mathrm{~m}^{2}, 9 \mathrm{~m}^{2}$, 51.744368, 36.171928 (7.07.2008);

K11 - Kursk, southern slope of the earth embankment near the sports stadium "Mercury" on Tuskarnaya street, $8 \mathrm{~m}^{2}, 51.750806,36.206996$ (27.06.2008);

K12, K13, K14 - Kursk, plots of the railway embankment, 0.7-1 km south of the station, 18 $\mathrm{m}^{2}, 12 \mathrm{~m}^{2}, 15 \mathrm{~m}^{2}, 51.742191,36.227882$ (21.07.2008);

K15, K19 - Kurchatov, plots on the bank of the water reservoir on Naberezhnaya street in front of the house no. 13, $12 \mathrm{~m}^{2}, 9 \mathrm{~m}^{2}, 51.659253,35.690802$ (9.07.2016);

K16 - Kursk, wasteland on Pogozhaya street near the house no. 51, $15 \mathrm{~m}^{2}, 51.775804$, 36.169102 (8.07.2016);

K17 - Zheleznogorsk, wasteland on Marshal Zhukov street near the house no. 6, $25 \mathrm{~m}^{2}$, 52.360981, 35.345695 (06.08.2016);

K18 - Zheleznogorsk, wasteland near the filling service station no. 15 on Lenin street, $9 \mathrm{~m}^{2}$, 52.362839, 35.344313 (06.08.2016);

K20 - Zheleznogorsk, wasteland on Isyskatelskaya street in front of the house no. 2, $9 \mathrm{~m}^{2}$, 52.321101, 35.373021 (07.08.2016);

K21 - Kursk, playground on Shkolnaya street near the house no. 54, $12 \mathrm{~m}^{2}, 51.769422$, 36.173793 (26.08.2016);

K22 - Kursk, roadside near the silicate brick factory on Silikatny passage, $18 \mathrm{~m}^{2}, 51.656878$, 36.083739 (17.08.2014).

Minsk. Author of relevés - E. Ya. Kulikova

M1 - wasteland on the left bank of the Svisloch river, $0.2 \mathrm{~km}$ east of the bridge on Goloded street, $35 \mathrm{~m}^{2}, 53.846728,27.651192$ (23.07.2007);

M2 - wasteland near the construction site, $0.3 \mathrm{~km}$ northeast of the Minsk ring road bridge over the railway "Minsk-Osipovichi", $15 \mathrm{~m}^{2}, 53.834977,27.560856$ (09.07.2006);

M3 - wasteland in Altayskiy lane, $16 \mathrm{~m}^{2}, 53.876292,27.667681$ (28.07.2007);

M4 - wasteland on the right bank of the Svisloch river, $0.1 \mathrm{~km}$ east of the Sheypichi village, $12 \mathrm{~m}^{2}, 53.867492,27.583319$ (29.08.2006);

M5 - wasteland between the railway and private houses in Krasivyy lane, $15 \mathrm{~m}^{2}, 53.885625$, 27.542183 (03.07.2005);

M6 - plot near drainage channels in Uruchye microdistrict, $33 \mathrm{~m}^{2}, 53.939117,27.693961$ (10.06.2007); 
M7 - lower section of the road slope on Tashkentskaya street, $12 \mathrm{~m}^{2}, 53.854678,27.635306$ (23.07.2007);

M8 - wasteland on Kolesnikov street, $15 \mathrm{~m}^{2}$, 53.920122, 27.436272 (13.08.2006);

M9 - wasteland on the right bank of the Myshka river, $40 \mathrm{~m}^{2}, 53.862183,27.507422$ (20.09.2006);

M10 - wasteland on the left bank of the Loshitsa river, $23 \mathrm{~m}^{2}, 53.856506,27.503117$ (17.09.2006);

M11 - wasteland on Orlovskaya street, $14 \mathrm{~m}^{2}, 53.929458,27.528356$ (08.10.2013);

M12 - disturbed plot as a result of construction work near the bridge and Loshitsky park, 24 $\mathrm{m}^{2}, 53.860692,27.581508$ (05.10.2013).

Republic of Bashkortostan. Author of relevés - Ya. M. Golovanov

R1 - Sterlitamak, railway embankment slope, $0.5 \mathrm{~km}$ north of the railroad crossing in the area of Otradovka, $25 \mathrm{~m}^{2}, 53.600376,55.917420$ (14.06.2014);

R2-R5 - Sterlitamak, wasteland on Artyom street near the house no. 104, sites along the heat pipeline, $10 \mathrm{~m}^{2}, 25 \mathrm{~m}^{2}, 25 \mathrm{~m}^{2}, 25 \mathrm{~m}^{2}, 53.625171,55.902960$ (12.06.2014);

R6, $\mathbf{R 7}$ - Sterlitamak, wasteland on Artyom street near the house no. 138, sites along the heating main, $9 \mathrm{~m}^{2}, 25 \mathrm{~m}^{2}, 53.621996,55.905642$ (12.06.2014);

R8, R9 - Sterlitamak, wasteland on Karanay Muratov street near the house no. 10, $25 \mathrm{~m}^{2}, 15$ $\mathrm{m}^{2}$, 53.617074, 55.897316 (12.06.2014);

R10 - Sterlitamak, wasteland $0.2 \mathrm{~km}$ north of the railway bridge over the Sterlya river, $25 \mathrm{~m}^{2}$, 53.607765, 55.918941 (14.06.2014);

R11-R13 - Salavat, sites along the heating main, $0.8 \mathrm{~km}$ north of the Optical-mechanical plant, $50 \mathrm{~m}^{2}, 64 \mathrm{~m}^{2}, 40 \mathrm{~m}^{2}, 53.345350,55.899924$ (26.06.2009);

R14-R20 - Salavat, 116th quarter, sites along the heating main, $0.8 \mathrm{~km}$ south of the Sadovaya street, $64 \mathrm{~m}^{2}, 64 \mathrm{~m}^{2}, 25 \mathrm{~m}^{2}, 64 \mathrm{~m}^{2}, 64 \mathrm{~m}^{2}, 25 \mathrm{~m}^{2}, 64 \mathrm{~m}^{2}, 53.356648,55.894846$ (26.06.2009)

Subass. typicum var. Ambrosia artemisiifolia includes early successional phytocoenoses. Similar communities within the ass. Melilotetum albo-officinalis are described on railway banks in the Czech Republic and are assigned to the var. Potentilla argentea. As a consequence of regular disturbances, they are composed mainly of biennial and annual species. They are often dominated by Echium vulgare (Chytrý 2009). In the coenoflora of the var. Ambrosia artemisiifolia described in the Kursk region, the allergenic invasive species Ambrosia artemisiifolia is present with high constancy. The relevés of the association from other parts of our study area do not include this species. This is explained by the fact that the Kursk region is located at the northern border of the widespread distribution of $A$. artemisiifolia, and therefore it is quite common there in various ruderal habitats (Reznik 2009; Arepieva 2019). North of the Kursk region, ragweed is less common, as well as in the Republic of Bashkortostan, where it is often damaged by early autumn frosts and cannot form viable seeds (Abramova 2011).

The coenoflora of subass. tussilaginetosum farfarae is characterized by the significant part of eury- and suboceanic species (Agrostis gigantea, Dactylis glomerata, Festuca pratensis, Tanacetum vulgare, Tussilago farfara, etc.). Most of these relevés were made in the northwestern part of the studied area in the cities of Minsk and Bryansk, located in the forest zone. In the most continental part (steppe 
zone and the southern part of the forest-steppe zone in the Republic of Bashkortostan), they are not identified.

Tab. 5 The significance of differences between pairs of syntaxons. Asterisks indicate significant differences $\left(*-p<0.05,{ }^{*}-p<0.01\right)$. Numbers of syntaxa and symbols of ecological factors: see note to Fig. 2.

\begin{tabular}{ccccc}
\hline Ecological factors & & $\mathbf{2}$ & $\mathbf{3}$ & $\mathbf{4}$ \\
\hline $\mathbf{M}$ & $\mathbf{1}$ & $0.069^{*}$ & $0.000^{* *}$ & 0.343 \\
& $\mathbf{2}$ & & 0.108 & $0.011^{*}$ \\
& $\mathbf{3}$ & & & $0.000^{* *}$ \\
\hline & $\mathbf{1}$ & 0.625 & 0.483 & 0.131 \\
$\mathbf{R}$ & $\mathbf{2}$ & & 0.401 & 0.120 \\
& $\mathbf{3}$ & & & $0.011^{* *}$ \\
\hline & $\mathbf{1}$ & 0.917 & 0.112 & 0.349 \\
$\mathbf{N}$ & $\mathbf{2}$ & & 0.102 & 0.289 \\
& $\mathbf{3}$ & & & 0.307 \\
\hline & $\mathbf{1}$ & 0.452 & 0.826 & $0.014^{* *}$ \\
$\mathbf{L}$ & $\mathbf{2}$ & & 0.362 & 0.157 \\
& $\mathbf{3}$ & & & $0.000^{* *}$ \\
\hline & $\mathbf{1}$ & $0.000^{* *}$ & $0.036^{*}$ & 0.971 \\
$\mathbf{T}$ & $\mathbf{2}$ & & $0.000^{* *}$ & $0.000^{* *}$ \\
& $\mathbf{3}$ & & & $0.000^{* *}$ \\
\hline & $\mathbf{1}$ & 0.268 & $0.000^{* *}$ & 0.685 \\
$\mathrm{C}$ & $\mathbf{2}$ & & $0.042^{*}$ & 0.170 \\
& $\mathbf{3}$ & & & $0.000^{* *}$ \\
\hline \multirow{2}{*}{$\mathrm{Hem}$} & $\mathbf{1}$ & $0.001^{* *}$ & 0.359 & 0.368 \\
& $\mathbf{2}$ & & $0.000^{* *}$ & $0.000^{* *}$ \\
& $\mathbf{3}$ & & & $0.046^{*}$ \\
\hline
\end{tabular}

It should be noted that this subassociation was first described in the northern regions of Slovakia (Jarolímek et al. 1997). Its differential species are Melilotus albus (dominant), Arctium tomentosum, Crepis biennis, Tussilago farfara. A comparison of the communities described by us with those from Slovakia revealed a significant similarity in their floristic compositions, which allowed us to relate them to this subassociation. The similarity is that their coenofloras contain a high share of mesophilous species of the class Molinio-Arrhenatheretea (Dactylis glomerata, Lotus corniculatus, Trifolium hybridum, T. pratense, etc.) and from other classes (Daucus carota, Tussilago farfara, Medicago lupulina). The differential group of Slovakian syntaxa contains Arctium tomentosum, which is the diagnostic species of subass. carduetosum acanthoidis. This is probably due to the strong anthropogenic impact on communities described in Slovakia.

In the Czech Republic (Chytrý 2009), the most mesophytic communities of the Melilotetum albo-officinalis are included into the variant Agrostis capillaris. They are also rich in mesophilous meadow and ruderal species (Agrostis tenuis, Poa trivialis, Ranunculus repens, Rumex obtusifolius, Trifolium hybridum, Tussilago farfara, Vicia 
cracca) many of which are found in communities of the subassociation described in Slovakia, as well as in communities we have identified.

In Lithuania, meadow species are more abundant and xeromesophytes are less represented in phytocoenoses of the Melilotetum albo-officinalis compared to communities from Central Europe. Such phytocoenoses are identified as the variant typica and are the most common in the region (Motiekaityté 2001). They are dominated by Melilotus albus and contain many highly constant species in common with the above-mentioned subass. tussilaginetosum farfarae (Dactylis glomerata, Daucus carota, Phleum pratense, Trifolium pratense, Tussilago farfara, etc.).

Comparing the floristic composition of mesophytic communities of the Melilotetum albo-officinalis described in Europe, we can conclude that they have a significant similarity, and therefore they can be considered as the subass. tussilaginetosum farfarae. Such communities are most common in the northern and central regions of Europe, while toward the south and east they become less frequent, occurring mainly in mesic habitats.

Subassociation carduetosum acanthoidis, on the contrary, includes relevés of xeromesophytic communities, described mainly in the eastern part of the study area - in the forest-steppe and steppe zones of the Republic of Bashkortostan, where they are widespread. As compared with other subassociations, its coenoflora contains a higher proportion of subcontinental and continental species (Arctium tomentosum, Berteroa incana, Carduus acanthoides, Euphorbia virgata, Sisymbrium loeselii).

Communities with similar floristic composition were identified in some European countries. In the Czech Republic (Chytrý 2009) and in Lithuania (Motiekaityté 2001), they are identified as the variant Carduus acanthoides with a high proportion of xerophilous species. In Lithuania, these communities rarely occur in this region and were found on the very steep slopes with southern exposure.

In the southern regions of Slovakia (Jarolímek et al. 1997), a subassociation brometosum tectori Jarolímek et al. 1997 of the Melilotetum albo-officinalis has been described. Xerothermophilous species prevail in it. Its differential species are Anchusa officinalis, Anisantha tectorum, A. sterilis, Berteroa incana, Bromus mollis, Cardaria draba, Centaurea pseudomaculosa, Eryngium campestre, Hordeum murinum, Lepidium ruderale, Onopordum acanthium, Poa angustifolia, $P$. compressa, Reseda lutea, Silene vulgaris. In contrast to phytocoenoses, recorded in our study, communities of this subassociation contain many indicator species of xerothermic habitats (e.g. Anchusa officinalis, Cardaria draba, Centaurea pseudomaculosa, Eryngium campestre, Hordeum murinum, Onopordum acanthium, Reseda lutea, etc.) and more species with southern distribution (Cerinthe minor, Rapistrum perenne, Verbascum phlomoides, Verbena officinalis, etc.). Similar communities are described in the southern part of Ukraine (Solomakha et al. 1992). The diagnostic taxa are Melilotus officinalis, M. albus, Echium vulgare, Daucus carota, Anchusa officinalis, Medicago lupulina, Reseda lutea, Achillea millefolium, Cichorium intybus. Its coenoflora has a lot of xerophytes in common with subass. brometosum tectori. 
Based on a comparison of the species composition, it can be assumed that the subass. carduetosum acanthoidis includes similar phytocoenoses of association described in the central and northern regions of Europe. Its communities are most common in continental regions of Eastern Europe. In Central Europe, they are formed mainly in habitats with xerothermic conditions, to the north, such communities rarely occur in the driest and warmest habitats.

In the southern regions of Europe communities of the subass. carduetosum acanthoidis are, most likely, replaced by communities of the subass. brometosum tectori with more xerothermophilous species composition and a high proportion of southern European taxa. The latter subassociation also includes the communities of ass. Melilotetum albo-officinalis described in southern Ukraine (Solomakha et al. 1992).

\section{Conclusion}

As a result of the revision and analysis, relevés of synanthropic communities dominated by Melilotus albus and $M$. officinalis from forest, forest-steppe and steppe zones of the European part of Russia and Belarus were assigned to the ass. Melilotetum albo-officinalis. Within, 3 subassociations were identified. Subass. typicum contains two variants. Var. typica includes the most typical communities. Such communities often contain few species due to the strong dominance of Melilotus albus and M. officinalis. Var. Ambrosia artemisiifolia includes early successional phytocoenoses affected by regular disturbances. The most mesophytic communities which are rich in mesophilous meadow and ruderal species are assigned to the subass. tussilaginetosum farfarae. Subass. carduetosum acanthoidis includes xeromesophytic communities. Its coenoflora contains highly constant species of the order Onopordetalia acanthi and a high proportion of subcontinental and continental species. The highest environmental differences of syntaxa were identified in the levels of moisture in soils and substrates, temperature, continentality and hemerobiality.

Some geographical regularities related to the location of the research area in different natural zones (forest, forest-steppe, steppe) and changes in the continentality gradient on its territory were found in the distribution of the established syntaxa.

Based on a comparison of the species composition of established syntaxa with similar syntaxa from other regions, it can be assumed that in Central and Eastern Europe, communities of the Melilotetum albo-officinalis belong to 4 subassociations that have ecological-geographical features. The mesophytic communities of the subass. tussilaginetosum farfarae are most common in the northern and central regions of Europe, and to the south and east they are less frequently found. Xeromesophytic communities of the subass. carduetosum acanthoidis are widespread in continental regions of Eastern Europe. In the central regions, they are formed mainly in habitats with xerothermic conditions. To the north, such communities rarely occur in the driest and warmest habitats. In the southern regions 
of Europe, communities subass. brometosum tectori with more xerothermophilous species composition and a high proportion of southern European taxa are described. Subass. typicum includes phytocoenoses, whose floristic composition and conditions place them in a transitional position between the above mentioned syntaxa. Such communities can be described throughout the distribution area of the association, but are likely to occur more frequently in its central part. Delimitation of variants corresponding to different successional stages of communities reflects the degree of anthropogenic disturbances.

\section{Acknowledgement}

The authors are grateful to RNDr. Ivan Jarolímek (Institute of Botany, Slovak Academy of Sciences, Slovakia) for providing data for floristic comparisons and to DSc. Prof. Eugene Postnikov (Kursk State University, Kursk, Russian Federation) for the correction of the English text. This study was partially funded by the state budget (№ AAAA-A18-118011990151-7).

\section{References}

Abramova L. M. (2011): Classification of communities with invasive species in the Southern Urals. I. Communities with Ambrosia species. - Vegetation of Russia. 19: 3-28. [in Russian] Abramova L. M. \& Golovanov Ya. M. (2016): Review of synantropic higher vegetation units of the European part of Russia. - Collection of scientific papers GNBS. 143: 7-15. [in Russian]

Arepieva L. A. (2015): The synanthropic vegetation of the Kursk city. - Kursk, 203 pp. [in Russian]

Arepieva L. A. (2017): The vegetation on railway embankments of the Kursk region. Vegetation of Russia. 30: 3-28. [in Russian] DOI: 10.31111/vegrus/2017.30.3.

Arepieva L. A. (2019): Communities with Ambrosia artemisiifolia L. in the Kursk region. Vegetation of Russia. 36: 41-58. [in Russian] DOI: 10.31111/vegrus/2019.36.41

Bagrikova N. A. (2016): The study of the synanthropic vegetation of the Crimean peninsula from the item of the ecological-floral approach: the state of the issue, the classification of communities and the prospects for research. - Collection of scientific papers GNBS. 143: 25-58 [in Russian]

Borhidi A. (2003): Magyarország növénytársulásai. - Akadémiai Kiadó, Budapest. 610 pp.

Brandes D. (1981): Über einige Ruderalgesellschaften von Verkehrsanlagen im Kölner Raum. - Decheniana 134: 49-60.

Brandes D. (1982): Das Sambucetum ebuli Felf. 1942 im südlichen Mitteleuropa und seine geographische Gliederung. - Tuexenia 2: 47-60.

Braun-Blanquet J. (1964): Pflanzensoziologie. Grundzuge der Vegetationskunde. 3 Aufl. SpringerVerlag, Wien-New York, 865 pp. DOI: 10.1007/978-3-7091-8110-2

Bulokhov A. D. \& Kharin A. V. (2008): Vegetation cover of the city of Bryansk and its suburban zone. - Bryansk, $310 \mathrm{pp}$. [in Russian]

Chytrý M. (ed.) (2007): Vegetace České republiky 1. Travinná a keříčková vegetace. Academia, Praha, $525 \mathrm{p}$.

Chytrý M. (ed.) (2009): Vegetace Česke republiky. 2. Ruderálni, plevelová, skalní a sutova vegetace. - Academia, Praha, $524 \mathrm{p}$.

Chytrý M., Tichý L., Holt J., Botta-Dukát Z. (2002): Determination of diagnostic species with statistical fidelity measures. - J. Veg. Sci. 13/1: 79-90. 
DOI: 10.1658/1100-9233(2002)013[0079:DODSWS]2.0.CO;2

Dengler J. \& Wollert H. (2004): Klasse: Artemisietea vulgaris Lohmeyer \& al. ex von Rochow 1951 - Ausdauernde Ruderalgesellschaften und Säume frischer bis trockener, stickstoffreicher Standorte. - In: Berg, C., Dengler, J., Abdank, A., Isermann, M. (eds.). Die Pflanzengesellschaften Mecklenburg-Vorpommerns und ihre Gefährdung - Textband, $p$. 380-410. - Weissdorn-Verlag, Jena.

Dierßen K. (1996): Vegetation Nordeuropas. - Stuttgart, 838 p.

Ellenberg H., Weber H. E., Düll R., Wirth V., Werner W., Paulssen D. (1992): Zeigerwerte von Pflanzen in Mitteleuropa. - Scripta Geobot. 18/2: 1-258.

Golovanov Ya. M. \& Abramova L. M. (2012): Vegetation of Salavat town (Bashkortostan Republic). III. Synanthrope vegetation (classes Bidentetea tripartitae, Stellarietea mediae and Artemisietea vulgaris). - Vegetation of Russia 21: 34-65. [in Russian]

Golovanov Ya. M., Petrov S. S. \& Abramova L. M. (2017): Flora and vegetation of the Sterlitamak town: current state and features of rational use. - Ufa, 312 pp. [in Russian]

Govorov E. V. (2004): Vegetation of rural localities in the North-East of the Republic of Bashkortostan: Author's abstract. - Dis ... Cand. biology sciences. Ufa, 16 pp. [in Russian]

Hammer O., Harper D. A. T. \& Ryan P. D. (2001): PAST: Paleontological statistics software package for education and data analysis. - Palaeontol. Electron. 4 (1). https://palaeoelectronica.org/2001_1/past/past.pdf.

Hennekens S. M. (1995): TURBO(VEG). Software package for input, processing, and presentation of phytosociological data. User's guide. Instituut voor Bos en Natuur, Wageningen and Unit of Vegetation Science, University of Lancaster, Lancaster, $70 \mathrm{pp}$.

Ilminskikh N. G. (1993): Florogenesis in an urban environment (on the example of cities of Vyat-ka-Kama region): Abstract ... Dr. Sci. in Biology thesis]. Saint-Petersburg, 35 pp. [in Russian]

Ishbirdin A. R., Mirkin B. M., Solomeshch A. I., Sakhapov M. T. (1988): Syntaxonomy, ecology and dynamics of ruderal communities in Bashkortostan. - Ufa, 161 pp. [in Russian]

Jarolímek I., Zaliberová M., Mucina L., Mochnacký S. (1997): Rastlinné spoločenstvá Slovenska, 2. Synantropná vegetácia. - Veda, Bratislava. 416 pp.

Kulikova E. Ya. (2012): Syntaxonomy structure and technogenic pollution of grassy vegetation of Minsk city. - Dis ... Cand. biology sciences. Minsk, 514 pp. [in Russian]

Matuszkiewicz W. (2007): Przewodnik do oznaczania zbiorovisk roślinnych Polski. Ed. 3. Warszawa, $537 \mathrm{~s}$.

Mirkin B. M. \& Naumova L. G. (2012): Current state of the main concepts of vegetation science. - Ufa, $488 \mathrm{pp}$. [in Russian]

Motiekaityté V. (2001): Plant associations of Dauco-Melilotion alliance in Lithuania. Biologija 2: 91-95.

Mucina L. (1981): Die Ruderalvegetation des nördlichen Teils der Donau-Tiefebene 2. Gesellschaften des Dauco-Melilotion-Verbandes auf ruderalen Standorten. - Fol. Geobot. Phytotax. 16/4: 347-389. doi.org/10.1007/BF02852418

Mucina L. (1989): Syntaxonomy of the Onopordum acanthium communities in temperate and continental Europe. - Vegetatio 81: 107-115. doi.org/10.1007/978-94-009-2432-1_8

Mucina L. (1991): Vicariance and clinal variation in synanthropic vegetation. - In: Nimis P. L. \& Crovello T .J. (eds.) Quantitative Approaches to Phytogeography, p. 263-276. - Kluwer, Dordrecht.

Mucina L. \& Brandes D. (1985): Communities of Berteroa incana in Europe and their geographical differentiation. - Vegetatio 59: 125-136. doi.org/10.1007/BF00055682 
Mucina L., Bültmann H., Dierßen K., Theurillat J.-P., Raus T., Čarni A., Šumberová K., Willner W., Dengler J., Gavilán García R., Chytrý M., Hájek M., di Pietro R., lakushenko D., Pallas J., Daniëls F. J. A., Bergmeier E., Santos Guerra A., Ermakov N., Valachovič M., Schaminée J. H. J., Lysenko T., Didukh Y. P., Pignatti S., Rodwell J. S., Capelo J., Weber H. E., Solomeshch A., Dimopoulos P., Aguiar C., Hennekens S. M., Tichý L. (2016): Vegetation of Europe: hierarchical floristic classification system of vascular plant, bryophyte, lichen, and algal communities. - Appl. Veg. Sci. 19(1): 3-264. DOI: 10.1111/avsc.12257

Pott R. (1995): Die Pflanzengesellschaften Deutschlands. Ed. 2. - Stuttgart, 622 S.

Reznik S. Ya. (2009): Factors determining geographic ranges and population densities of common ragweed Ambrosia artemisiifolia L. (Asteraceae) and the ragweed leaf beetle Zygogramma suturalis F. (Coloeoptera, Chrysomelidae). - Plant protection news 2: 2028. [in Russian]

Rostanski K., Dzhus M., Gudzinskas Z., Rostanski A., Shevera M., Sulcs V., Tokhtar V. (2004): The genus Oenothera L. in Eastern Europe. - W. Szafer Institute of Botany, Polish Academy of Sciences, Krakow, 133 p.

Sanda V., Öllerer K., Burescu P. (2008): Fitocenozele din România sintaxonomie, structură, dinamică şi evoluţie. - Edit. Ars Docendi, Bucureşti, 570 pp.

Schubert R. (2001): Prodromus der Pflanzengesellschaften SachsenAnhalts. Mitteilungen zur floristischen Kartierung Sachsen-Anhalt, Sonderheft 2. - Herausgegeben vom Botanischen Verein Sachsen-Anhalt e.V. Halle/Saale, $689 \mathrm{~s}$.

Solomakha V. A. (2008): The syntaxonomy of vegetation of the Ukraine. The third approximation. - Phytosociocentre, Kyiv, 296 pp. [in Ukrainian]

Solomakha V. A. Kostylov O. V., Shelyah-Sosonko Yu. R. (1992): Synanthropic vegetation of Ukraine. - Naukova dumka, Kyiv, 252 pp. [in Ukrainian]

Ter Braak C. J. F. \& Šmilauer P. (2002): CANOCO Reference Manual and CanoDraw for Windows User's Guide: Software for Canonical Community Ordination (version 4.5). Ithaca, NY, USA, $500 \mathrm{p}$.

Tichý L. (2002): JUICE, software for vegetation classification. - J. Veg. Sci. Vol. 13/3: 451-453. DOI: 10.1111/j.1654-1103.2002.tb02069.x

Weber H. E., Moravec J. \& Theurillat J.-P. (2000): International Code of Phytosociological Nomenclature. 3rd edition. - J. Veg. Sci. 11: 739-768. DOI: 10.2307/3236580

Westhoff V. \& van der Maarel E. (1973): The Braun-Blanquet approach. - In: Whittaker R. H. (ed.): Handbook of vegetation science, part 5, Classification and ordination of communities. - Junk, The Hague: 617-726. DOI: 10.1007/978-94-009-9183-5_9

Zverev A. A. (2007): Information technologies in studies of vegetation cover: A training manual. - Tomsk, 304 pp. [in Russian]

Received: February $17^{\text {th }} 2020$

Revised: June $22^{\text {nd }} 2020$

Accepted: July $1^{\text {st }} 2020$ 